Andersen, D.C. - Narrowleaf cottonwood ecohydrology

\title{
Climate, streamflow, and legacy effects on growth of riparian Populus angustifolia in the arid San Luis Valley, Colorado
}

\author{
Douglas C. Andersen \\ U.S. Geological Survey, Fort Collins Science Center \\ 2150 Centre Avenue, Building C \\ Fort Collins, CO 80526-8118
}

doug_andersen@usgs.gov

This draft manuscript is distributed solely for purposes of scientific peer review. Its content is deliberative and predecisional, so it must not be disclosed or released by reviewers. Because the manuscript has not yet been approved for publication by the U.S. Geological Survey (USGS), it does not represent any official USGS finding or policy.

\section{Abstract}

Knowledge of the factors affecting the vigor of desert riparian trees is important for their conservation and management. I used multiple regression to assess effects of streamflow and climate (12-14 years of data) or climate alone (up to 60 years of data) on radial growth of clonal narrowleaf cottonwood (Populus angustifolia), a foundation species in the arid, Closed Basin portion of the San Luis Valley, Colorado. I collected increment cores from trees $(14-90 \mathrm{~cm}$ $\mathrm{DBH}$ ) at four sites along each of Sand and Deadman creeks (total $N=85$ ), including both perennial and ephemeral reaches. Analyses on trees $<110 \mathrm{~m}$ from the stream channel explained $33-64 \%$ of the variation in standardized growth index (SGI) over the period having discharge measurements. Only 3 of 7 models included a streamflow variable; inclusion of prior-year conditions was common. Models for trees farther from the channel or over a deep water table explained $23-71 \%$ of SGI variability, and 4 of 5 contained a streamflow variable. Analyses using solely climate variables over longer time periods explained 17-85\% of SGI variability, and 10 of 12 included a variable indexing summer precipitation. Three large, abrupt shifts in recent decades from wet to dry conditions (indexed by a seasonal Palmer Drought Severity Index) coincided with dramatically reduced radial growth. Each shift was presumably associated with branch dieback that produced a legacy effect apparent in many SGI series: uncharacteristically low SGI in the year following the shift. My results suggest trees in locations distant from the active channel rely on the regional shallow unconfined aquifer, summer rainfall, or both to meet water demands. The landscape-level differences in the water supplies sustaining these trees 
Andersen, D.C. - Narrowleaf cottonwood ecohydrology

implies variable effects from shifts in winter- versus monsoon-related precipitation, and from climate change versus streamflow or groundwater management.

KEYWORDS: climate variation; ephemeral stream; groundwater; narrowleaf cottonwood; Palmer Drought Severity Index; tree rings

SHORT TITLE: Narrowleaf cottonwood ecohydrology 
Andersen, D.C. - Narrowleaf cottonwood ecohydrology

\section{1. Introduction}

2 Riparian plant communities are key contributors to local and regional biodiversity,

3 particularly in arid and semiarid regions (drylands) where their physiognomic heterogeneity and

4 high productivity support unique arrays of consumer, detritivore, and decomposer organisms

5 (Levick et al., 2008; Soykan et al., 2012). The nature of dryland riparian plant communities, in

6 turn, is strongly dependent on local streamflow and groundwater conditions (Stromberg and

7 Merritt, 2015). This dependency makes these communities vulnerable to disruption by water

8 resource management activities and has resulted in dramatic declines in desert riparian habitat

9 extent and quality, both in the western United States (Andersen et al., 2007; Obedzinski et al.,

10 2001) and globally (Tockner and Stanford, 2002). In the drylands of the western U.S., the

11 precipitation decline predicted to accompany climate change (Perry et al., 2012) is likely to

12 further alter riparian communities as local hydrologic regimes respond to shifts in catchment

13 water budgets. These vulnerabilities have prompted research to acquire the knowledge and

14 develop the tools for long-term management of remaining dryland riparian plant communities.

15 These efforts rely on understanding how species respond to fluvial-geomorphic, hydrological,

16 and other environmental conditions (Rood et al., 2005; Shafroth et al., 2010).

17 Dryland riparian woodlands in North America commonly contain tree species from the

18 genus Populus, i.e., a cottonwood or poplar. These trees serve as foundation species, defining

19 floodplain forest structure and controlling ecosystem dynamics (Ellison et al., 2005). Although

20 much is known about the autecology of some Populus species, narrowleaf cottonwood ( $P$.

21 angustifolia James) has received relatively little attention despite its distribution in Rocky

22 Mountain riparian habitats from southern Canada to northern Mexico (Argus et al., 2010).

23 Dryland narrowleaf cottonwoods are obligate phreatophytes, with a root system generally

24 confined to the soil's upper few meters (Pregitzer and Friend, 1996; Rood et al., 2011), making

25 shallow groundwater during the growing season a necessary condition for population persistence.

26 The species is dioecious and wind-pollinated, producing small, short-lived seeds dispersed by

27 wind and water. However, individuals also readily expand clonally through production of root

28 sprouts (Braatne et al., 1996; Gom and Rood, 1999). Plants are relatively tolerant of physical

29 disturbance, including flooding. These traits contribute to narrowleaf cottonwood commonly

30 serving as a pioneer species on floodplains. 
Andersen, D.C. - Narrowleaf cottonwood ecohydrology

Narrowleaf cottonwood is the only tree present in the northern portion of the San Luis Valley (SLV), a large $\left(8300 \mathrm{~km}^{2}\right)$, high altitude $(2300 \mathrm{~m})$ cold-desert basin in south-central

33 Colorado. The trees form discontinuous bands along perennial and ephemeral stream channels

34 that carry runoff from the adjacent Sangre de Cristo Mountains through federally owned and

35 protected lands within Great Sand Dunes National Park and Preserve and neighboring Baca

36 National Wildlife Refuge. In the early 2000s, biologists noted branch dieback in many of these

37 trees, indicative of past or ongoing physiological stress from drought (Rood et al., 2000) or other

38 factor. A regional drought had indeed begun in 1999 (Henz et al., 2004), but another potential source of stress was groundwater pumping near the park and refuge boundaries. The pumping had begun in the mid-1980s when the federal Closed Basin Project began extracting $>10^{6} \mathrm{~m}^{3}$ of shallow groundwater annually from the SLV for delivery to the Rio Grande for downstream use (Reclamation, 2003).

Annual growth in mature dryland riparian Populus can be strongly correlated with factors affecting the water table and plant-available soil water (Andersen, 2016; Edmondson et al., 2014; Meko et al., 2015). Further, severe water stress can cause crown dieback (Rood et al., 2000) and is associated with greatly restricted radial growth (Scott et al., 2000; Scott et al., 1999). Thus, interannual variation in radial growth provides a means to assess a tree's history of exposure to water stress. Confounding the relationship, however, is the fact that dieback - a permanent loss of a portion of the tree's canopy_might produce at least a short-term legacy of restricted growth, even if environmental conditions are highly favorable, until lost primary production is replaced through canopy expansion and restoration of former leaf area.

Here I add to the autecological knowledge of narrowleaf cottonwood and assess the potential causes of dieback in the northern SLV by testing the hypothesis that interannual variation in radial growth of adult trees can be largely explained by interannual variability in climate and/or associated stream flow. I compare the factors affecting growth in spatial groups of trees near to and far from the stream channel at multiple sites along two streams in order to gain insight into whether summer precipitation associated with the North American monsoon is an important contributor to growth of SLV cottonwoods. By focusing on how growth is linked to streamflow,

59 water table dynamics, and years having unusual climate conditions during the growing-season, I

60 provide insight into the hydrological mechanisms sustaining these trees and the presence and 61 magnitude of legacy effects. That focus also provides a means to assess the potential adverse 
Andersen, D.C. - Narrowleaf cottonwood ecohydrology

62 effects from the Closed Basin Project through a before-and-after comparison of growth patterns

63 in trees closest to the project's extraction wells.

\section{2. Materials and methods}

\subsection{Study Area}

I worked along Sand and Deadman creeks in Great Sand Dunes National Park and Preserve and the Baca National Wildlife Refuge in south-central Colorado (Figure 1). Both creeks have their headwaters in the 4,000 -m high Sangre de Cristo Mountains and flow westward into the Closed Basin portion of the SLV, where their channels terminate in a playa complex (Mayo et al., 2007). Streamflow at the mountain front is probably perennial, whereas flow becomes ephemeral as one moves away from the alluvial fans of the mountain front and onto the "sand sheet" making up much of the valley floor. High infiltration rates in the channel beds (Hadlock et al., 1997; Harte et al., 2007) result in the streamflow-derived riparian water table declining with lateral distance from the channel (Wurster et al., 2003). Depth to the riparian water table also varies spatially due to topographic variation in the riparian zone produced through aeolian and fluvial geomorphic processes.

Both Deadman and Sand creeks feature a snowmelt-driven spring flood pulse. This pulse has been subject to human manipulation in reaches on the sand sheet. Sheep and cattle ranchers, present in the SLV since at least the mid-1800s, diverted flows to flood-irrigate valley floor areas for native grass (hay) production, but the location and frequency of diversions are unknown.

The valley floor climate is arid (mean annual precipitation $<250 \mathrm{~mm}$ ), whereas the creek headwaters receive more than $1000 \mathrm{~mm}$ of precipitation annually, primarily as snow. Winter temperatures $<-20{ }^{\circ} \mathrm{C}$ and summer temperatures $>30{ }^{\circ} \mathrm{C}$ are common; the warm season lasts 20-110 days (Mix et al., 2011). Groundwater associated with the unconfined regional aquifer in the Closed Basin is generally shallow, with depth to the water table decreasing from $>4 \mathrm{~m}$ at the Sangre de Cristo mountain front to $<2 \mathrm{~m}$ in the center of the basin (Emery et al., 1971).

I worked at four sites on each of Sand (Sites S1-S4) and Deadman (Sites D1-D4) creek, at or downstream of the creek's exit point along the mountain front (Figure 1). Site elevations ranged from $\sim 2480$ to $2300 \mathrm{~m} \mathrm{ASL}$, and the geomorphic setting and flow character varied along this elevation gradient (Table 1). To account for the streamflow-derived lateral gradient in depth to the water table, I sampled individual trees or tree clusters relatively near to and relatively far from the channel at sites where that was possible. To account for spatial variation in depth to the 
Andersen, D.C. - Narrowleaf cottonwood ecohydrology

93 water table due to local topography, I sampled trees on representative topographically-distinct

94 landforms and over any elevation gradient present (Figure 2). I avoided obviously injured or

95 unhealthy trees, but otherwise selected trees haphazardly, without regard to clone boundaries or

96 local stem density. For analysis, trees were grouped as being close to or far from the active

97 stream channel. For example, trees sampled near the channel at Sand Creek Site S2 were

98 grouped as "S2-Near" trees, and trees sampled at Deadman Creek Site D3 but far from the

99 channel were grouped as "D3-Far" trees. The Closed Basin Project's eastern boundary, within

100 which extraction wells were located, was $\sim 3 \mathrm{~km}$ downstream of the lowest study site on each

101 creek (D4 and S4; Figure 1), with the closest extraction wells in each case $\sim 5 \mathrm{~km}$ away.

$102 \quad 2.2$ Methods

103 2.2.1 Surface water hydrology and climate

104 I examined two streamflow and nine climate variables for an effect on P. angustifolia radial 105 growth (Table 2). Flow data for Sand and Deadman creeks have been collected since 1993 and

106 1999, respectively, at gauges located near each stream's point of entry onto the valley floor

107 (Figure 1). I obtained discharge records from the Colorado Division of Water Resources [e.g.,

108 recent daily mean and instantaneous discharge at 15-minute intervals (uncorrected) at

109 http://www.dwr.state.co.us/surfacewater/data/division.aspx?div=3] or the National Park Service

110 (pre-2006 Sand Creek daily mean discharge data; Andrew Valdez, personal communication).

111 Gauge names are "Sand Creek near stream entrance into GRSA" (2005 and earlier), "Sand Creek

112 at Great Sand Dunes National Park" (codename SANDUNCO), "Deadman Creek near Crestone"

113 (codename DEDCRECO) and the latter's replacement, "Deadman Creek at mouth of canyon

114 near Crestone" (DEDMOUCO).

115 I generated values for 3- and 30-day maximums (Qм3 and Qм30) for the spring run-off

116 period (1 May through 15 July) from the daily discharge data using the Indicators of Hydrologic

117 Alteration software package (The Nature Conservancy; Version 7.0.0 Beta 4.10). Discharge

118 records were missing for 2003 in Sand Creek and 2000 in Deadman Creek. I estimated the

119 missing summary statistics using regression equations relating flows in these streams to those in

120 nearby streams (Supplementary Online Material Table A-1). Because prior-year environmental

121 conditions can affect growth even in the absence of dieback (Rood et al., 2013), I assessed both

122 current year and prior-year values of Qм3 as well as Qм30. 
Andersen, D.C. - Narrowleaf cottonwood ecohydrology

I obtained monthly mean air temperature and total monthly precipitation data for the period 1951-2012 for Station 53541 (Great Sand Dunes National Monument, Colorado) from the Western Regional Climate Center (http://www.wrcc.dri.edu/cgi-bin/cliMAIN.pl?cogrea). A key missing datum (September 2006 precipitation) was estimated by regressing September values on those from the nearest station having data for that month (Station 050776, Blanca, Colorado; $n=$ $\left.52, P<0.001, \mathrm{r}^{2}=0.60\right)$. I based inclusion of the monthly temperature variables (Table 2 ) on the premise that a warm March or April reduces growth (because it reduces mountain snowpack development or initiates early runoff), whereas a warm May or June is beneficial (because it promotes a higher growth rate in the early portion of the growing season, given adequate moisture conditions). Daily meteorological data for the same station were obtained from the Colorado Climate Center (http://ccc.atmos.colostate.edu/dly_form.html). I quantified overall favorability of growing season moisture and temperature conditions using values of the Palmer Drought Severity Index for US Climate Division 5 in Colorado (Rio Grande Basin) obtained from the NOAA National Centers for Environmental Information (http://www7.ncdc.noaa.gov/CDO/CDODivisionalSelect.jsp). The Palmer Index (Palmer, 1965) uses temperature and precipitation data in a formula to determine region-specific relative dryness (or wetness) on a monthly basis. A value of 0.0 represents average or normal dryness. Negative values indicate drought, with $-2,-3$, and -4 indicating moderate, severe, and extreme drought, respectively. Comparable positive values indicate wet conditions, e.g., +3 indicates a severe wet period. I created a seasonal index (Table 2: PDSIs) by averaging monthly values for January through July. This 7-month period includes months when the mountain snowpack would be accumulating as well as the period of snowmelt and high stream discharge, and the earlythrough mid-growing season periods when local rainfall and air temperature would directly affect tree growth. Along with current-year values, I also assessed prior-year values for both PDSIs and total June through August precipitation (Ps).

\subsubsection{Regional groundwater hydrology}

Water table elevations in the regional unconfined aquifer have been monitored since the 1980s as part of the Closed Basin Project (CBP), which involved the installation of 170 groundwater extraction wells in five temporally- and spatially-distinct stages between the early 1980s and mid-1990s. Stages 1-3 began delivering water in 1986 and stages 4 and 5 began delivering water in 1992 and 1993, respectively (Reclamation, 2003). My lowest study reaches 
Andersen, D.C. - Narrowleaf cottonwood ecohydrology

154 on Sand and Deadman creeks are $<4 \mathrm{~km}$ outside (east and upstream) of the Stage 3 and Stage 4 155 project area boundaries, respectively. I examined records of annual stage-specific CBP pumping volumes as well as water table elevations in three CBP monitoring wells (available at

157 http://www.prinmath.com/rgwcd/loc/ewlist.htm) located between those study reaches and the 158 Stage 3 and Stage 4 project areas to gain insight into whether the pumping could have affected water table elevations at my study sites. A CBP monitoring well was located $\sim 1 \mathrm{~km}$ from each of the Sand and Deadman creek channels (wells EW31 and EW54, respectively), and a third well (EW44) was located between Sand and Deadman creeks, $\sim 3.5 \mathrm{~km}$ south of the Deadman Creek channel (Figure 1).

\subsubsection{Study site water table depths and dynamics}

164 I monitored streamside groundwater dynamics for $\sim 2$-yr on each creek using observation 165 wells I installed at sites S4, D2 and D4 (Table 1; Figure 2). Shallow cobble stopped attempts to 166 install wells at upstream sites S1, S2 and D1. I placed casings, either capped PVC pipe with 167 hand-cut slots in the lowest meter or commercial slotted pipe, in hand-augered holes that I then 168 back-filled with native sand. I added a layer of bentonite clay powder $(\geq 1 \mathrm{~cm}$ thick) around the casing 15-20 cm below the ground surface. I placed continuously-recording water table sensors in five wells, and manually read water table position in nine others (Table 1).

I used a Total Station to survey the location of, and the local ground surface elevation at, 172 each sampled tree at Sand Creek sites S1, S2, and S4. I also surveyed points in the stream 173 channel bed and each well casing top and local ground surface. I mapped the active channel 174 margin and well locations at S4, and trees at S3, using a hand-held GPS device (Garmin 175 GPSMap 60CS). I determined the elevation of a single point (either well casing top or the 176 ground surface) relative to mean sea level using real time kinematic GPS at Deadman Creek sites

177 D2, D3, and D4. I mapped sampled tree locations at all four Deadman Creek sites using the GPS 178 device, whereas a Total Station was used to survey well tops and ground surface elevation at 179 trees in sites D2 and D4.

\subsubsection{Dendrochronology}

181 I used a $25-\mathrm{cm}$ increment borer to obtain $5-\mathrm{mm}$ cores from mature $(\geq 14 \mathrm{~cm}$ diameter at

182 breast height; DBH) trees (ramets) when leaf-drop was underway in 2007 (Sand Creek) and 2010 183 (Deadman Creek). A total of 71 trees were sampled along Sand Creek and 25 along Deadman 184 Creek. 
Andersen, D.C. - Narrowleaf cottonwood ecohydrology

I typically collected a single core (Sand Creek) or two perpendicular cores (Deadman Creek) at breast height $(\sim 1.3 \mathrm{~m})$ from each tree; a total of 136 cores were collected for processing. I airdried and mounted each core and sanded its surface to a final 600 grit ( $26 \mu \mathrm{m})$. I delineated rings and measured their widths $(0.01 \mathrm{~mm}$ precision) using a binocular microscope and measuring stage featuring a linear encoder and digital readout coupled to program Measure $2 \mathrm{X}$. I visually cross-dated the raw ring-width series in each spatial group following the method of Yamaguchi (1991), generally using 1981, 1996 and 2002 as marker years because of their consistently narrow widths. In cases where simple adjustment (e.g., correction for a false or missing ring) did not result in relatively narrow rings for those years, I repeated the sanding, reading, and cross-dating process to confirm ring boundaries and widths before assignment of a ring's production year (PY). Program COFECHA ver. 6.06P (Grissino-Mayer, 2001) was used to provide further insight into possible cross-dating errors.

I detrended each series where regression indicated a significant $(P<0.05)$ negative exponential or linear age-trend was present. I assessed age trend using a modified 3-parameter single exponential decay model:

$$
\mathrm{Y}=\mathrm{a} \cdot \exp [\mathrm{b} /(\mathrm{t}+\mathrm{c})]
$$

where $\mathrm{Y}=$ ring width, $\mathrm{t}=$ calendar year, and $\mathrm{a}, \mathrm{b}$, and $\mathrm{c}$ are constants. This model is similar to the modified negative exponential model (Cook et al., 1990), but it produced higher $\mathrm{r}^{2}$ values in test trials. Positive linear trends in ring width series were treated as real, and the associated series detrended, because of the possibility that conditions unrelated to hydrology, such as release from competition, were operating. I used SigmaPlot 2002 and SigmaPlot 11 for model fitting.

I standardized each series to account for differences in age trend and absolute growth rate among individual trees by dividing actual ring width by either the width predicted from the detrending model or the mean width in those series where no significant trend was detected (Cook et al. 1990). I generated final interseries correlation and sensitivity values for the standardized growth index (SGI) series for trees within each group using program COFECHA. The SGI series for selected trees identified in the COFECHA output as contributing to low interseries correlation values was examined for patterns that might provide insight into their contrary growth pattern, e.g., evidence of differential sensitivity to drought. For example, where annual growth in two trees within a group was divergent in a number of multi-year periods (i.e., 
Andersen, D.C. - Narrowleaf cottonwood ecohydrology

216 periods in which one SGI $>>0$ and the other SGI $<<0$, intermixed with periods when the

217 opposite pattern occurred), I used stepwise-forward logistic regression in an attempt to determine

218 if any climate variable(s) could be used to predict when one or the other pattern would be

219 evident.

220 I calculated the mean SGI series for each spatial group without regard to incongruities

221 among the individual tree SGI series that remained after cross-dating. I assumed any incongruity

222 present represented real differences in growth patterns and that the mean SGI series represented

223 the population-level response of trees (ramets) at that locality to environmental conditions.

224 2.2.5 Statistical evaluation of climate and hydrologic effects on annual growth

225 I used a two-stage process to test for an effect from environmental variables on annual

226 growth (mean SGI value) in each group ("Near" and "Far") at each site. For the first stage, I

227 used forward stepwise multiple linear regression analysis in an analysis limited to 1994-2007

228 (Sand Creek) or 1999-2010 (Deadman Creek), periods for which complete spring and summer

229 stream discharge data were available. Thus, all streamflow and climate variables could be

230 included in the analysis, although prior-year streamflow data were not available for 1994.

231 A time series of climate, streamflow, or SGI values will tend to show positive

232 autocorrelation, because measurements close in time will tend to be similar - a result of climate

233 being affected by multi-year phenomena like the Pacific Decadal Oscillation. Using an

234 autocorrelated time series in a statistical procedure that assumes independent observations, e.g.,

235 linear regression, is temporal pseudoreplication, and although the model parameter estimates are

236 unbiased, their estimated standard errors can be either too large or too small, depending on the

237 nature of the autocorrelation. Because attempting to remove autocorrelation in short time series

238 introduces other uncertainties (Bence, 1995), I elected to use "uncorrected" values in my

239 multiple regression analyses. Thus, although the models I produce are accurate in terms of the

240 incorporated variables, model significance and $\mathrm{R}^{2}$ values require subjective interpretation. In

241 particular, models with $P$ values close to 0.05 may not, in fact, be statistically significant at the $\alpha$

$242=0.05$ level.

243 Stage 2 involved a second round of forward stepwise multiple regression, performed as

244 above but using only climate variables and over the longest time period possible (typically set

245 the mean SGI series length). For both the Stage 1 and Stage 2 analyses, I compared and 
Andersen, D.C. - Narrowleaf cottonwood ecohydrology

contrasted variables and their manner of entry into models for the "near" and "far" spatial groups. All regression analyses were performed using SYSTAT 11.

To assess whether and when dieback legacy effects were present I first inspected the climate data for exceptionally dry years that might have been sufficiently stressful to result in branch dieback. The subsequent year was then considered a legacy-year candidate, i.e., a year in which growth would be much lower than expected based on climate or streamflow conditions. I assessed whether legacy effects were present by sequentially excluding the candidate years in each of the datasets used in the multiple regression analyses. I expected to see an increase in model $\mathrm{R}^{2}$ values after reanalysis with the reduced dataset.

I tested for an effect from CBP groundwater pumping on the Sand Creek trees closest to the project boundary, i.e., the 16 trees in the S4-Far group farthest from the channel (Figure 2, cluster G). I independently tested for an effect in three subgroups that differed in depth to groundwater as a result of their positions along a sandhill topographic gradient (S4-LOW, -MID, and $-\mathrm{HIGH}, n=8,2$, and 6 trees, respectively). The surface elevation difference between the low and high subgroups was $\sim 3 \mathrm{~m}$. I used sequential ANOVAs to compare the relationship between SGI and PDSIs before and after pumping began, first testing for a difference in slope of the relationship, and then, given no difference in slope, testing for a difference in intercept.

\section{Results}

\subsection{Valley floor climate}

Precipitation on the valley floor is bimodal, with long-term data indicating a peak in May and an even larger peak in August (Supplementary Online Material Figure A-1). Total annual monsoon-related precipitation (July through October) during 1991-2012 (the period when stream discharge was being monitored) ranged from 86 to $239 \mathrm{~mm}$ (Supplementary Online Material Figure A-2). Summer (June through August) precipitation (Ps) ranged from 50 to $189 \mathrm{~mm}$ during the same period (Figure 3), reflecting the strong dependence of $\mathrm{PS}_{\mathrm{S}}$ on monsoon-related precipitation $(\mathrm{r}=0.79, P<0.001, n=22)$. A regional drought that began in 1999 (Henz et al., 2004) was well documented in the very low January through May ( $\left.\mathrm{Pw}_{\mathrm{w}}\right)$ and annual precipitation totals for 2002 (Figure 3).

The seasonal Palmer Drought Severity Index (PDSIs) values document regional drought reaching severe levels in the 1930s, 1950s, and 2000s (Figure 4, upper panel). PDSIs and Pw were only weakly correlated $(r=0.26, P=0.052 ; n=57)$. Three unusually large between-year 
Andersen, D.C. - Narrowleaf cottonwood ecohydrology

shifts in conditions from relatively moist to dry (difference between consecutive PDSIs values < -6) were concentrated in a 25-year period, and occurred in years that had been independently selected during core processing as marker years for cross-dating: 1981, 1996, and 2002. No other year in the 20th century was characterized by a shift of similar magnitude (Figure 4, lower panel). Further, in all three cases the shift to dry conditions followed $\geq 2$ years that featured moist and relatively stable PDSIs values (Figure 4, lower panel). I focused on these three years to assess whether dieback, assuming it had occurred, produced a subsequent legacy effect.

Several other recent years featured growing-season weather patterns that might have dramatically affected cottonwood growth. The 1987 PDSIs was the highest since 1942 (Figure 4 upper panel) and followed a series of very wet years. Record single-day and total monthly August precipitation ( 4.5 and $11.8 \mathrm{~cm}$, respectively) were recorded at the Crestone climate station (Figure 1). A series of three wet years terminating in 1999, which featured a PDSIs = 3.96, resulted in the 1999 growing-season conditions being similar to those of 1987 . The running 3-yr mean $P_{w}$ for the period ending in 1999 was the $3^{\text {rd }}$ largest in the 1951 to 2010 period. Finally, the spring and summer of 1995 was unusually cold. The monthly mean temperature for May $\left(8^{\circ} \mathrm{C}\right)$ was the lowest in the 1951-2007 period, and that followed the $9^{\text {th }}$ coldest April, and preceded the fifth coldest June. Snow fell in April, May and June and three record low daily minimum temperatures occurred in July.

\subsection{Stream hydrology}

Discharge in Sand Creek typically exceeds that in Deadman Creek, and both creeks show large interannual variation during the spring and summer months. There was essentially no spring flood in 2002, and monsoon-related storms produced flash floods in several years (Figure 5). Sand Creek $\mathrm{Q}_{\mathrm{m} 3}$ and $\mathrm{Q}_{\mathrm{m} 30}$ values were at most only moderately correlated to PDSIs ( $\mathrm{r}=0.15$ and 0.50, respectively; Table 3), and neither flow variable was correlated to PDSIs in Deadman Creek $(\mathrm{r}<0.09)$. Qм30 was strongly correlated to $\mathrm{Pw}$ at both Sand Creek $(r=0.77$; Table 3$)$ and Deadman Creek ( $r=0.71, P=0.009, n=12)$.

Sand Creek discharge was comparatively low during spring and summer 2006 (Figure 5). A large flash flood (maximum mean daily flow $5.7 \mathrm{~m}^{3} \mathrm{~s}^{-1}$ ) was recorded in mid-August, but the channel at Site S4 was dry when first visited three weeks later. In 2007, snowmelt produced a surface flow that filled the $\mathrm{S} 4$ channel by mid-May, but flow had ended by mid-July. The presence of surface flow at S4 in 2007, a year of moderate peak discharge and QM3 
Andersen, D.C. - Narrowleaf cottonwood ecohydrology

(Supplementary Online Material Figure A-3), suggests that a spring flow is present in the S4 reach most years.

Flow in the lowest Deadman Creek reach, D4, was subject to manipulation, and it is unclear whether surface water reached there during either the 2011 or 2012 spring flood. On 22 May 2012, I witnessed a diversion in operation between D3 and D4, and the channel at D4 was dry.

\subsection{Water table depths and dynamics}

3.3.1. Patterns in the study observation wells (sites S4, D2 and D4).- The absolute elevation of the water table in Sand Creek reach S4 declined with distance from the channel at least from early spring into autumn in both 2007 and 2008 (Figure 6A), indicating the presence of a lateral, channel-to-floodplain hydraulic gradient during the growing season. A longitudinal gradient was also present (e.g., from SW11 to SW6), reflecting the east-to-west hydraulic gradient from the Sangre de Cristo mountain front to the Closed Basin's central playa complex (Figure 6A). The water table at S4 showed a seasonal rise and fall in concert with the rise and fall in Sand Creek discharge, with the magnitude of the rise inversely related to distance from the active channel (Figure 7A). The water table appeared to be at or near its annual minimum by mid-October.

The autumn minimum groundwater elevation at S4 was higher in 2007 than in 2006, reflecting the higher summer flows of 2007 (Figure 5), but the interannual difference declined with distance from the channel, dropping from $\sim 15 \mathrm{~cm}$ at the channel margin (Well SW6) to only $3 \mathrm{~cm}$ at a distance of $600 \mathrm{~m}$ (Well SW1; Figure 7B). During the 2007 growing season, daily water table fluctuations of 5- to $\sim 15-\mathrm{cm}$ were recorded under cottonwoods in Well SW2 (Figure 6B). Based on survey data and observed groundwater dynamics, the estimated mean depth to the water table at S4 ranged from $\sim 1.0$ to $2.5 \mathrm{~m}$ under the S4-Near trees, whereas it ranged from 1.6 to $5.0 \mathrm{~m}$ under the S4-Far trees (Table 4).

Groundwater dynamics in the Deadman Creek reaches differed markedly from those in Sand Creek's S4 reach. At D2, the water table beneath cottonwoods growing $100 \mathrm{~m}$ from the incised channel rose slowly during autumn 2010, reached a winter high in February 2011—when creek discharge was low - and then began a very slow decline (Figure 6D). The water table was only a few centimeters below its February peak in mid-May, when it began to rise in concert with the 2011 spring flood pulse in Deadman Creek. That flood was relatively small and the response of the water table was a modest $\sim 10 \mathrm{~cm}$ rise to the level reached the previous February (Figure 6D). The water table then tracked the receding limb of the flood pulse, falling by late summer to a 
Andersen, D.C. - Narrowleaf cottonwood ecohydrology

level $\sim 36 \mathrm{~cm}$ below its previous mid-winter level. A similar autumn-through-late winter rise was observed in each of the following two years. Circadian water table fluctuations were noted under D2 trees during the growing season (Figure 6E). No comparable daily fluctuations were observed along either stream in the continuously-monitored wells located away from trees (wells SW1, SW3, and DW2). Mean water table depths at D2 were estimated to be $\sim 1.7 \mathrm{~m}$ under the trees in the D2-Near group and ranged from $\sim 1.7$ to $\sim 3.0 \mathrm{~m}$ under the trees in the D2-Far group (Table 4).

The water table in reach D4 (Well DW2) also slowly rose through the winter. In 2011, a high point was reached in early May (Figure 6D), $\sim 2$ weeks prior to a brief rise of $\sim 18 \mathrm{~cm}$ that coincided with the spring flood pulse. As at D2, the water table then declined through the summer months (Figure 6D). The D4 water table dropped below the sensor position from August 2011 to February 2012, but a total decline of $\sim 0.5 \mathrm{~m}$ from the previous peak appears reasonable based on the shapes of the declining and rising limbs of the associated curve (Figure 6D). In Spring 2012, there was a rapid rise in the D4 water table to a level $\sim 70 \mathrm{~cm}$ higher than it had reached the previous year, but the rise abruptly ended and the water table dropped precipitously in mid-May.

The November 2010 survey data indicated a mean $0.43 \%$ slope for the water table between D2 and D4. This slope yields a depth to the water table under D3 trees of $\sim 3.7 \mathrm{~m}$ at that time, assuming a planar water surface.

3.3.2. Patterns in the CBP observation wells.-Well EW31 was nearest CBP Stage 3, where pumping began in 1986 and production peaked in 1989 (Figure 8C). Records collected prior to initiation of pumping show the late autumn (November) water table dropping $\sim 35 \mathrm{~cm}$ between 1982 and 1983 and rising $~ 50 \mathrm{~cm}$ between 1983 and 1984. This decline and rise contrasts with the prevailing climate conditions, which were dry in 1982 (PDSIs $=-1.27)$, became wet in 1983 $($ PDSIs $=1.88)$ and even wetter in $1984($ PDSIs $=2.89)$.

Despite 1985, 1986, and 1987 being consecutively more wet than 1984 (Figure 4 upper panel), the November water table in EW31 dropped $69 \mathrm{~cm}$ between 1986 and 1987, coincident with initiation of the Stage 3 pumping (Figure 8C). (There are no Autumn 1985 data.) A 19861987 decline (44 cm) was also evident at Well EW54 (September records), near D4 (Figure 8B), although pumping had yet to start in the nearby Stage 4 area. Another large interannual decline $(55 \mathrm{~cm})$ was recorded in EW31 in the 1991-1992 November data, which coincided with initiation 
Andersen, D.C. - Narrowleaf cottonwood ecohydrology

of Stage 4 pumping. The decline contrasted with climate conditions, which were wet in 1990 and became very wet in both 1991 and 1992 (Figure 4 upper panel). No interannual fluctuation in a monthly record comparable to those at wells EW31 or EW54 was apparent at Well EW44 (Figure 8A).

The monthly water table elevations collected in the three CBP wells since the mid-1990s indicate the water table associated with the regional unconfined aquifer is consistently lowest in late-summer or autumn and highest in late-winter to early-spring (March-April; Figure 8). The 2007-2008 water table fluctuations in well EW31, near Sand Creek, show little similarity to those noted at S4 (Figure 6A and C), other than having an autumn minimum. In contrast, the 2011-2013 fluctuations in Well EW54, near Deadman Creek, clearly show the winter rise and summer decline observed at D2 and D4 (Figure 6D and F). There is no evidence in the EW31 record of the Sand Creek flood pulse affecting the spring-to-autumn water table decline there (Figure 6C), nor is there evidence of the Deadman Creek flood pulse affecting water table dynamics at EW54 (Figure 6F).

\subsection{Streamflow and climate effects on narrowleaf cottonwood growth}

Cores from 85 of the 96 sampled trees produced ring series with reliable PY assignments that extended to at least the beginning of the streamflow record. The longest series extended to the 1920s. Most trees showed distinctively narrow rings in 1981, 1996, and/or 2002 (Table 5). Trees also tended to show above-average growth in unusually-wet 1987 and below-average growth in unusually-cold 1995 (Table 5).

Interseries correlations of the mean SGI series varied from near zero to 0.46 (Table 5). Low values were generated where neighboring trees showed very different growth patterns. For example, the very low value for the D2-Near group of four trees was due in part to two trees that showed contrasting positive and negative SGI values during multiple, often lengthy periods ( $\mathrm{r}$ $=-0.33, P=0.014$ ). Which tree grew best varied among the periods (Figure 9). Logistic regression using years when one pattern $(n=14)$ or its opposite $(n=14)$ was evident suggested that $\mathrm{T}_{\text {MAR }}$ was a determining factor (odds ratio $=0.73 ; 95 \%$ confidence interval $<1.0$ ), although model fit was poor (McFadden's $\rho^{2}=0.16$ ). The model suggested that when TMAR was low (e.g., $30^{\circ} \mathrm{F}$ ), the probability of one tree having an above-average SGI while the other had a below-average SGI was relatively high (0.78), whereas that probability fell to a relatively low value $(0.28)$ when TMAR was high (e.g., $\left.37^{\circ} \mathrm{F}\right)$. An even more complex pattern was observed at 
Andersen, D.C. - Narrowleaf cottonwood ecohydrology

S1-Near, where all four trees appeared to be competing or otherwise responding independently to environmental conditions, leading to essentially no interseries correlation (Table 5).

3.4.1. Trees near the channel-Seven of the eight sites had trees growing quite close to the channel. The exception was D3, where the closest trees were $>160 \mathrm{~m}$ away. For most "near" trees, the distance to the channel was $<30 \mathrm{~m}$, but trees up to $\sim 100 \mathrm{~m}$ away were included in the S4 "near" group (Table 4; Figure 2). A single SGI series was available to represent streamside trees at D1. I used the series in a Stage 1 analysis, but pooled the series with those from streamside trees at S2, which featured a similar physical environment (Table 1), for the Stage 2 analysis.

The Stage 1 "recent-years only" analyses using the full datasets produced models for only two of the six "near" groups (S1- and S2-Near) and the single D1-Near tree. No model was produced for the D2-, D4-, S3- or S4-Near trees. However, exclusion of 1996 and legacycandidate year 1997 from the S4-Near dataset resulted in a model, as did the exclusion of legacycandidate years 1997 and 2003 from the D4-Near data set (Table 6). Exclusion of both 1997 and 2003 failed to produce a model for either S3- or S4-Near trees (Table 6). Scatterplots identified 1996 (and 1972) as well as 1997 as outliers, with the 1996 SGI for S3-Near trees the lowest in the 50-yr series. Exclusion of 2003 failed to produce a model for D2-Near trees, but a model resulted from the exclusion of 1999, identified as a year of unusual weather. The seven models nominally explained from 33 to $64 \%$ of the variation in the SGI series during recent years (Table 4).

The mix of independent variables included in these seven Stage 1 models varied widely (Table 4); only two variables, $\mathrm{P}_{\mathrm{W}}$ and $\mathrm{P}_{\text {SMAX, }}$, were not included in a model. A variable indexing summer precipitation was included in five models, in all cases through an inverse relationship between precipitation and growth. Streamflow variables were included in three of the four models for trees along Sand Creek; no streamflow variable was included in the model for S3, where the stream had incised and trees were over a very deep ( $\geq 3 \mathrm{~m}$ ) water table. No model developed for Deadman Creek streamside trees included a streamflow variable. The water table was deep at D2, and moderately deep at D4. Water table depth at D1 was judged to be relatively shallow, but true depth and its dynamics were unknown. Four of the seven Stage 1 models included prior-year variables. 
Andersen, D.C. - Narrowleaf cottonwood ecohydrology

Inspection of the ring-width series for streamside trees at Site S2 indicated dramatically different growth patterns before and after 1987 (Supplementary Online Material Figure B-1). Because a major change in local environmental conditions was likely responsible for the shift, I performed separate Stage 2 analyses over the pre- and post-1987 periods for the S2-Near trees.

The Stage 2 "longest-period possible" analyses for the streamside groups produced models in five of the six possible cases. No model was produced for D4-Near trees even with the exclusion of legacy-candidate years 1997 and 2003, but scatterplots indicated 2002 also to be an outlier and its additional exclusion led to a significant model. Most variation in SGI at D4 was explained by an inverse relationship with prior-year Ps (Table 4). Overall, the Stage 2 models explained less of the variation in the SGI series (15 to 48\%) than did the Stage 1 models. The variables included in the Stage 2 models often mirrored to some degree those in the Stage 1 model for the same trees. For example, the annual variation in SGI of S1-Near trees during 1994-2007 (Stage 1 analysis) was explained to a large extent by a model that contained current year Ps, prior-year Ps, and Qм30, whereas annual variation over the full 52-yr long SGI series (1955-2007) was explained (to a much smaller extent) by a combination of current-year Ps and TMAY (Table 4). Sand Creek QM30 was negatively correlated to TMAY $(r=-0.77)$ during the discharge measurement period (Table 3), and thus QM30 in the Stage 1 model might have been replaced by $\mathrm{T}_{\mathrm{MAY}}$ in the Stage 2 model, assuming their association remained strong over the entire 1955-2007 period. Five of the Stage 2 models for streamside trees contained a variable indexing summer precipitation, and in four of those models that variable explained most of the variation.

3.4.2. Trees far from the active channel-Five of the eight sites had tree groups classified as far from the channel. Actual distances separating the sampled trees from the channel varied among both trees and sites (Table 4). S1-Far trees were relatively close to the channel but growing on a surface well above the stream channel. I include them in the "far" group because of their relative isolation from the stream through the presumably deep water table present. The largest distances (> $500 \mathrm{~m}$ ) were for the majority of S4-Far trees (Figure 2: Group G). The SGI series for individual S2-Far trees showed a growth pattern shift ca. 1987 similar to that noted in the S2Near trees, and I again split the SGI series into pre- and post-1987 periods for the Stage 2 analysis (Table 4). Site S2 was the only location where such an abrupt shift in growth pattern was observed. 
Andersen, D.C. - Narrowleaf cottonwood ecohydrology

The Stage 1 analysis produced a model for four of the five tree groups; no variable was entered into a model for S4-Far trees. Exclusion of legacy-candidate year 1997, however, resulted in a model for $\mathrm{S} 4-$ Far trees that explained $71 \%$ of the variation in the recent SGI series (Table 4). A scatterplot of each year's SGI and PSMIN values (Figure 10) confirmed the 1997 SGI as being an extremely low-value outlier. Overall, the five models explained from 23 to $71 \%$ of the variation in the recent SGI series.

Four of the five models included a streamflow variable, and in all cases it was the prior-year value. An index of summer precipitation was included in three models, and in all cases is was the current-year value (Table 4).

The Stage 2 analyses produced six models, including the two pre- and post-1987 models for S2-Far trees. Those two models were quite different, both in terms of the variables included and the amount of variation explained (Table 4). Overall, the six models explained from 22 to $85 \%$ of the variation in SGI values for trees growing far from the channel (Table 4).

Variables indexing summer precipitation were included in five of the six models. PSMIN was the leading explanatory variable in two models (post-1987 S2-Far and D2-Far) and included in two others. Current-year PDSIs was the leading explanatory variable in two models (S1-Far and S4-Far). No variable indexing summer precipitation was included in the Stage 2 model for D3Far trees. However, a scatterplot of the D3-Far trees' mean SGI values and PSMIN values for the same year (Figure 10) revealed several outlier years, including legacy-candidate 1997, and

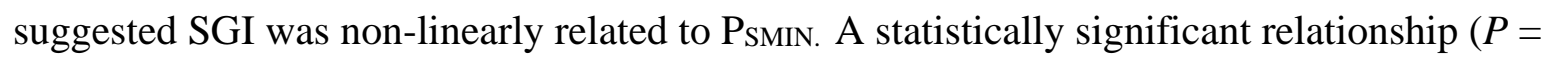
0.03) became evident when four outlier years (1987 and 1995-97) were removed. The uncharacteristic growth in each of 1987, 1995, and 1996 coincided with unusual weather conditions.

Inspection of scatterplots comparing SGI values for "near" and "far" groups across years identified years when conditions were more-or-less equally favorable or equally unfavorable to the two groups. For example, the SGI was extraordinarily high in all Site S1 trees in 1987 (Supplementary Online Material Figure B-2), suggesting conditions for growth at that site were exceptionally favorable that year. The SGI values for trees in groups D3-Far and S4-Far were also very high that year (Figure 10). An analysis using logistic regression to elucidate a relationship between climate condition and the years in which the growth pattern dramatically differed between "near" and "far" trees was unfruitful. 
Andersen, D.C. - Narrowleaf cottonwood ecohydrology

\subsection{Evidence for a legacy effect on cottonwood growth}

I tested for the presence of dieback legacy effects in 10 tree groups (Table 6) distributed over six sites. Exclusion of a legacy-candidate year increased $R^{2}$ values in six of 17 Stage 1 models and 7 of 28 Stage 2 models (Table 6). Five of the six Stage 1 confirmations involved 1997, whereas five of the seven Stage 2 confirmations involved 2003. The presence of a legacy effect in 1982 was supported solely in the D2-Near trees.

\subsection{Evidence for an effect from CBP groundwater pumping}

The test for an effect from CBP groundwater extraction on the S4-LOW, -MID, and -HIGH trees detected an effect only in the S4-HIGH trees, which were growing on the highest landform and thus over the deepest groundwater (Table 7). All three groups showed similar fluctuations in SGI from 1985 through 1989 - the period that spanned both the start and peak level of CBP pumping - and those fluctuations generally matched the expected responses to changes in PDSIs. However, the ANOVA for the S4-HIGH group indicated a shift in the relationship of SGI to PDSIs after CBP pumping began. Despite mean PDSIs values for 1966-1986 and 1987-2007 being nearly identical (1.327 and 1.331, respectively), growth in the S4-HIGH trees was depressed after pumping began $(P=0.050)$.

\section{Discussion}

\subsection{Climate and streamflow effects on growth.}

The very low interseries correlations for some groups (Table 5) could reflect inaccurate ring chronologies, a possibility that cannot be completely dismissed. However, a large effort was made to ensure ring-series accuracy and trees, even close neighbors, could clearly differ in their growth pattern (Figure 9). Moreover, the presence of such differences is not unexpected, given the potential for large between-tree variability in physiological condition in some years (e.g., variation in legacy effects associated with differential presence/absence or extent of dieback) coupled with more general differences in sensitivity to environmental conditions (e.g., due to variation in root architecture, clonal integration level, intraspecific competition, browsing injury, or other factor). Assuming accurate chronologies, the mean SGI series used in the analyses approximate a tree group's "average" response to environmental conditions.

The results of the Stage 1 regression analyses over the 12 to 14 years for which hydrologic data were available support the hypothesis that variation in weather and/or streamflow can explain major proportions of the variation in narrowleaf cottonwood growth along Sand and 
Andersen, D.C. - Narrowleaf cottonwood ecohydrology

524 Deadman creeks. However, the paucity of positive relationships between growth and a current-

525 year streamflow variable was unexpected. This may reflect a relatively low probability of

526 insufficient soil water and very shallow depth to ground water commonly found under these

527 trees. The models indicated streamside trees had growth reduced by current-year factors

528 contributing to soil saturation at rooting depth during the growing season, particularly high levels

529 of summer precipitation. An inverse relationship to summer precipitation (as either PS or PSMIN)

530 was included in four of the seven models developed for such trees (Table 4), and in two cases

531 (S1- and S2-Near) the same relationship appeared in the Stage 2 model. Once saturated, a warm

532 soil can quickly become anoxic through $\mathrm{O}_{2}$ uptake by microbes, and roots in such soils may

533 cease to function or die (Cao and Conner, 1999; Pregitzer and Friend, 1996), either of which

534 would reduce growth in aboveground plant parts. The overriding importance of this constraining

535 influence on growth of streamside cottonwoods is further underscored by the common

536 occurrence of an inverse relationship to a prior-year streamflow or climate variable in the Stage 1

537 models. Late-growing season soil saturation the prior year would hinder production and storage

538 of carbon and other resources critical for early-season flower and foliage production.

539 Positive relationships between growth and environmental variables were more common in

540 the models for trees growing far from the channel. Although no Stage 1 model included a

541 current-year flow variable, inverse relationships to a prior-year flow variable appeared in several

542 (S4-, D2-, and D3-Far), suggesting these trees were not fully independent of the stream's

543 influence on the water table beneath them. Positive relationships to PDSIs, dominant in two

544 Stage 2 models (S1- and S4-Far) and contributors in three others (pre-1987 S2-, D2-, and D3-

545 Far) point to the importance of overall growing season moisture availability for these trees. The

546 prominence of a positive relationship to a monthly temperature in two groups (pre-1987 S2- and

547 D3-Far) could be interpreted to mean a warm spring is beneficial, but the particular variables

548 involved (TAPR and TMAY) were inversely correlated to Pw and Ps, as well as Sand Creek QM30

549 (Table 3) during the period when streamflow data were being collected. Thus, the effects of

550 temperature and moisture excess may be confounded, and remain to be resolved. Taken

551 together, the variability in the Stage 1 and Stage 2 models for the "near" and "far" tree groups

552 suggest a complex relationship exists among streamflow, the regional aquifer, and summer

553 precipitation in determining annual growth in these trees. The appearance of PSMIN or PS in the 
Andersen, D.C. - Narrowleaf cottonwood ecohydrology

554 majority of models points to the large effect from summer and monsoon precipitation on growth 555 in these trees.

\subsection{Evidence that Closed Basin cottonwoods are phreatophytic.}

All of the narrowleaf cottonwoods examined in this study must rely on groundwater to some extent for their survival. Given the small amount of precipitation directly deposited on valley floor landforms, soil moisture at mature cottonwood rooting depths is supplied primarily by either infiltrating stream water or by water in the regional unconfined aquifer. The phreatophytic nature of the trees in this study was demonstrated by the presence of circadian water table fluctuations under trees during the growing season (Figure 6B and 6E) (Gribovszki et al., 2010).

Narrowleaf cottonwood rooting depth varies with local soil moisture conditions, and can be relatively deep compared to other Populus species (Rood et al., 2011). Nevertheless, not all of

565 the cored trees may be independently phreatophytic. Wiehle et al. (2009) examined clonal stands of Euphrates poplar (P. euphratica) and found that ramets originating as root suckers did not

567 develop a deep tap root and maintained a connection to the parental tree for some years. How

568 long the parent-sucker connection remains functional in narrowleaf cottonwood is unclear, but in trembling aspen ( $P$. tremuloides) the connection can remain functional for many decades, even after the death of the aboveground part of the parent tree (DesRochers and Lieffers, 2001). The irregular topography in the riparian corridor produced strong differences in depth-to-the-water table under trees only 10-20 m apart. Thus, specific locations of ramets as well as the clone itself

573 may have influenced growth patterns. For example, water transfers between interconnected

574 ramets growing in low and high topographic positions may have reduced adverse effects from drought-induced water table decline or other environmental factor that stressed nearby but unconnected trees on the same high surface (Peltzer, 2002). Such differences could help explain

577 the low interseries correlation observed in some tree groups.

\subsection{Closed Basin shallow groundwater sources.}

Both Sand and Deadman creeks continuously lose water as they move away from the mountain front (Wurster et al., 2003), thereby contributing to annual recharge of the regional

581 shallow unconfined aquifer. Their water adds to that from the multitude of small channels along

582 the mountain front that contain surface flow only during spring snowmelt or other large runoff

583 events. Recharge by direct precipitation on the valley floor is probably minor, with the result 584 that the groundwater flow system recharges primarily along the entire Sangre de Cristo mountain 
Andersen, D.C. - Narrowleaf cottonwood ecohydrology

585

586

587

588

front and flows toward the Closed Basin center (Emery et al., 1971; Mayo et al., 2007). A groundwater wave is presumably generated each year by mountain snowmelt and rainfall runoff that produces both diffuse and focused surface and subsurface contributions to the unconfined aquifer (mountain-front recharge).

At both wells SW1 and DW1, most distant from the channel, the decline in the water table that coincided with the recession of the spring flood flows (Figure 6A and 6D) indicates that hydraulic conductivity is high and any rise in the riparian water table produced by stream flooding lasts only as long as the flood. This implies that the water table's annual autumn minimum, subsequent rise and winter peak at Deadman site D2 is determined by conditions in the regional unconfined aquifer. The 2011 wave peak reached site D2 in about mid-February and site D4 in mid-May (Figure 6C), suggesting 3 months were required for the wave to travel the $4.5 \mathrm{~km}$ between the two sites. Given that D2 is $\sim 7 \mathrm{~km}$ from the mountain front and assuming a similar propagation speed, the wave can be estimated to have originated near the mountain front east of D2 during the spring-to-autumn runoff period of the previous year.

If this scenario is correct, the peak height of the water table at site D2 in February 2011 was determined primarily by the moderately-sized 2010 spring runoff, because monsoon-related runoff was slight. The 2012 groundwater pulse was in turn determined by 2011 spring snowmelt and monsoon-related runoff. Such a lag would explain the contrasting patterns in annual PDSIS values and water table dynamics noted in CBP observation well EW31 prior to the start of project pumping. The lag may also be responsible for D2 trees far from the channel showing a negative effect from prior-year PSMIN (Table 4). Whereas total summer rainfall tends to vary somewhat slowly over multiyear periods, $\mathrm{P}_{\text {SMIN }}$ reflects the nature of the driest summer month and varies sharply from near zero to high values almost annually (Supplementary Online Material Figure A-4). An above-average PSMIN immediately followed a well-below average PSMIN in 13 of the 57 years from 1951 to 2007, including 1995, 1999, 2003, and 2006.

\subsection{Narrowleaf cottonwood tree locations.}

The sampled trees growing far from the present channel presumably established in a different hydrologic environment, or the clonal parent tree did. Seed germination requires a moist surface and seedling establishment requires rooting zone moisture and a landscape position safe from desiccation and scour until the plant becomes phreatophytic. These conditions are typically provided by a streamside location (Baker, 1990). The sampled trees' current locations 
Andersen, D.C. - Narrowleaf cottonwood ecohydrology

616 far from the channel could be due to a shift in the active channel's position (e.g., avulsion during

617 a flood event) or channel abandonment (e.g., through a meander-neck breach). Such an event at

618 Site S2 might explain the 1987 shift in growth pattern observed in both the "near" and "far" tree

619 groups there. Alternatively, current "far" tree location could reflect seedling establishment

620 outside of the normal floodplain, incidental to flow diversions made as part of historic water

621 management operations.

6224.5 Groundwater sources, groundwater dynamics, and cottonwood dependencies.

623 Taken together, the models for tree growth and the information on regional and streamside

624 water table dynamics suggest trees near the channel are dependent on local streamflow whereas

625 trees far from the channel rely on the regional unconfined aquifer to supply soil moisture.

626 Interannual dynamics in the regional aquifer are less variable than those in the streamside water

627 table, suggesting environmental factors other than streamflow, e.g., growing season length,

628 growing season temperature, or seasonal precipitation, contribute more to variation in the SGI of

629 trees far from the channel. Early growing season temperature was variable in its role among

630 individual models, perhaps reflecting microclimatic differences among the tree group locations.

631 Warm early spring months may promote early foliage development and a longer growing season,

632 but they also increase the risk of foliage-killing spring frost in areas of cold-air drainage. Such

633 frosts would result in a shift in carbon allocation from wood production to development of

634 replacement foliage. A warm spring can also be detrimental when or where extensive foliage

635 development (high leaf area) combines with temperature-sensitive evaporative demand to

636 produce transpiration rates that exceed water uptake rates.

637 The poor model fit for some tree groups (e.g., S1-Far) might also reflect genetically-based

638 variability among neighboring trees in vulnerability to environmental stressors. Male narrowleaf

639 cottonwoods are less tolerant of flooding and may be more tolerant to drought than female trees

640 (Nielsen et al., 2010; Rood et al., 2010). Also, the initiation and ultimate extent of canopy

641 dieback is dependent on moisture stress history (Anderegg et al., 2013), as well as the presence

642 or absence of physical connections among ramet root systems (Gom and Rood, 1999). Finally,

643 relationships between SGI and climate or streamflow may have in some cases been masked by

644 effects from browsing. Elk (Cervus elaphus) were present at all eight study sites, and bison

645 (Bison bison) were present at Sand Creek site S4. Both species will browse cottonwoods. In a 4646 yr study overlapping this one, Schoenecker (2012) estimated that $47 \%$ of cottonwood sprouts and 
Andersen, D.C. - Narrowleaf cottonwood ecohydrology

647 twigs in the Closed Basin were browsed each year. The SLV elk population expanded from $648 \sim 1000$ to 5000 individuals during 1983-2000 (B. C. Lubow and K. Schoenecker, unpublished 649 data) and sampled trees that were young in the 1980s would have been directly vulnerable to 650 browsing. Older, larger trees, even if not browsed themselves, may be vulnerable to reductions 651 in SGI if they reallocate photosynthate from supporting radial growth to subsidizing regrowth in 652 browsed sprouts (Ishihama et al., 2014).

653 The uncharacteristically poor growth documented in the outlier years 1982, 1997, and 2003 654 strongly supports the notion that canopy dieback occurred in the drought years of 1981, 1996, 655 and 2002. The results from sequentially excluding the legacy-candidate years in the regression 656 analyses (Table 6) suggest dieback varied in intensity both spatially and temporally. Although 657 the 2002 dieback may have attracted the attention of the field biologists, it likely only added to 658 the number of dead branches already in the canopy.

659 Closed Basin Project pumping appeared to have reduced growth in trees closest to the 660 project boundary, but only those over the deepest groundwater (S4-HIGH). Detection of an 661 effect in neighboring but lower trees may have been hindered by the shorter pre-pumping SGI 662 series available for those trees (Table 7). The large 1986-1987 reduction in the water table at 663 wells EW31 and EW44 was almost certainly attributable to initiation of CBP Stage 3 pumping, 664 and the depression documented in those wells presumably reached site S4. The S4-LOW trees 665 showed growth patterns from 1985 through 1989 that could reasonably be explained as responses 666 to changes in PDSIs or associated climate variables. However, the greater depth to groundwater 667 under the S4-HIGH trees may have made them particularly sensitive to even a small drop in the 668 regional water table (Shafroth et al., 2000).

669 Although a small number of studies have examined environmental influences on growth in 670 naturally established narrowleaf cottonwood (e.g., Gom and Rood, 1999; Rood et al., 2013;

671 Willms et al., 2006), this is the first study to examine a population in the southern portion of its 672 range. My results are generally consistent with those of Rood et al. (2013), who found a strong 673 association between annual basal area increment and streamflow in mature narrowleaf 674 cottonwood on the regulated Oldman River in southern Alberta, Canada. They found a 675 combination of current- and prior-year mean growing season discharges could explain $36 \%$ of 676 the variation in annual growth over their 17-yr long study period. In contrast to my study, 
Andersen, D.C. - Narrowleaf cottonwood ecohydrology

677 however, growth in their trees was unrelated to local growing season precipitation or mean 678 temperature.

679 Studies of other riparian Populus species support the idea that these trees, through plasticity 680 of root and crown architecture, can adapt to changes in the water supply within certain limits.

681 Most notably, Scott et al. (1999) assessed effects of in-channel mining on growth in Plains 682 cottonwoods ( $P$. deltoides). They reported that a $0.5-\mathrm{m}$ gradual and permanent drop in the water 683 table caused only a small reduction in annual branch growth, and no branch dieback or change in 684 radial growth, whereas a 1-m permanent drop resulted in leaf desiccation, branch dieback, and 685 eventually the death of most sampled trees. Similarly, Scott et al. (2000) documented a greater 686 proportion of dead trees and reduced radial growth in stands of riparian Fremont cottonwood that 687 had been exposed to abrupt, sustained water table declines brought about by channel incision 688 and/or avulsion.

\subsection{Conclusions}

690 The narrowleaf cottonwoods fringing Sand and Deadman creeks depend on groundwater 691 supplied by the stream, by the regional aquifer, or both. With the caveat that the period of record 692 is short for both the stream discharge and water table elevation data (Kennard et al., 2010), I 693 conclude that stream discharge has little or no direct effect on the growth of cottonwoods 694 growing far from the channel. Instead, those trees now depend on the regional unconfined 695 aquifer, direct infiltration of growing-season precipitation, or both to meet their water demands.

696 Together, the Stage 1 and Stage 2 models indicate that local climate is an important determinant 697 of annual tree growth for most of the trees along Sand and Deadman creeks, and that prior-year conditions play a significant role. The difference in environmental conditions under which 699 seedlings establish and those under which many adult trees are currently living indicate the 700 species is adaptable to a changing hydrologic environment. Nevertheless, because of the reliance 701 of the trees on either streamflow or the regional shallow aquifer, factors affecting those sources 702 of water will influence tree radial growth and, presumably, overall tree vigor. Even within a site, 703 effects can be expected to differ among individual ramets based on their landscape position 704 (depth to groundwater) and the physical connections among root systems. Globally, populations 705 of dryland riparian trees in similar hydrologic settings can be expected to show similar variability 706 in water-source dependency. The full nature and extent of effects from groundwater declines 707 produced by the Closed Basin Project on nearby narrowleaf cottonwoods remain unclear. It is 
Andersen, D.C. - Narrowleaf cottonwood ecohydrology

clear, however, that streamflow diversion — or its elimination-has the potential to strongly affect these trees' productivity, as will any shift in winter or monsoon precipitation associated with global climate change.

\section{Acknowledgements}

John Wondzell helped with Sand Creek well installation, and Zack Wiebe and Katie Hagaman assisted with groundwater monitoring and flow observations. Rick Wydoski, Johnny Boutwell, and Miki Stuebe provided surveying and other field assistance. I thank them all. I also thank Ron Garcia (USFWS) for key logistical help, Fred Wurster for assistance in obtaining PDSI values, Fred Bunch and Andrew Valdez (NPS) for logistical help and data, Julie Roth and Greg Auble (USGS) for help in the dendrochronology lab, and Rich Roberts (USBR) for providing Closed Basin Project data. Special thanks to Andrew Valdez for conducting both the RTK-GPS and Total Station surveys at the Deadman Creek sites, and Brian Cade for statistical advice. Kate Schoenecker, Linda Zeigenfuss, and Jonathan Friedman provided helpful comments on the ms. This work was funded by the U. S. Geological Survey and the National Park Service. Any use of trade, firm, or product names is for descriptive purposes only and does not imply endorsement by the U.S. Government.

\section{References}

Anderegg, W.R.L., Plavcova, L., Anderegg, L.D.L., Hacke, U.G., Berry, J.A., Field, C.B., 2013. Drought's legacy: multiyear hydraulic deterioration underlies widespread aspen forest dieoff and portends increased future risk. Global Change Biology 19, 1188-1196. DOI: 10.1111/gcb.12100.

Andersen, D.C., 2016. Flow regime effects on mature Populus fremontii (Fremont cottonwood) productivity on two contrasting dryland river floodplains. The Southwestern Naturalist 61, 8-17. DOI: $10.1894 / 0038-4909-61.1 .8$

Andersen, D.C., Cooper, D.J., Northcott, K., 2007. Dams, floodplain land use, and riparian forest conservation in the semiarid Upper Colorado River Basin, USA. Environmental Management 40, 453-475. DOI: 10.1007/s00267-006-0294-7. 
Andersen, D.C. - Narrowleaf cottonwood ecohydrology

Argus, G.W., Eckenwalder, J.E., Kiger, R.W., 2010. Salicaceae Mirbel, willow family, in: Flora of North America Editorial Committee (Eds.), Flora of North America North of Mexico, Vol. 7. Oxford University Press, New York.

Baker, W.L., 1990. Climatic and hydrologic effects on the regeneration of Populus angustifolia James along the Animas River, Colorado. Journal of Biogeography 17, 59-73.

Bence, J.R., 1995. Analysis of short time series: correcting for autocorrelation. Ecology 76, 628639. DOI: $10.2307 / 1941218$.

Braatne, J.H., Rood, S.B., Heilman, P.E., 1996. Life history, ecology, and conservation of riparian cottonwoods in North America, in: Stettler, R.F., Bradshaw, H.D., Jr., Heilman, P.E., Hinckley, T.M. (Eds.), Biology of Populus and its implications for management and conservation. NRC Research Press, Ottawa, Canada, pp. 57-85.

Cao, F.L., Conner, W.H., 1999. Selection of flood-tolerant Populus deltoides clones for reforestation projects in China. Forest Ecology and Management 117, 211-220.

Cook, E.R., Briffa, K.R., Shiyatov, S.G., Mazepa, V.S., 1990. Tree-ring standardization and growth-trend estimation, in: Cook, E.R., Kairiukstis, L.A. (Eds.), Methods of Dendrochronology. Kluwer, Dordrecht, Netherlands, pp. 104-123.

DesRochers, A., Lieffers, V.J., 2001. The coarse-root system of mature Populus tremuloides in declining stands in Alberta, Canada. Journal of Vegetation Science 12, 355-360. DOI: $10.2307 / 3236849$.

Edmondson, J., Friedman, J., Meko, D., Touchan, R., Scott, J., Edmondson, A., 2014. Dendroclimatic potential of plains cottonwood (Populus deltoides ssp. monilifera) from the northern Great Plains, USA. Tree-Ring Research 70, 21-30. DOI: 10.3959/15361098-70.1.21.

Ellison, A.M., Bank, M.S., Clinton, B.D., Colburn, E.A., Elliott, K., Ford, C.R., Foster, D.R., Kloeppel, B.D., Knoepp, J.D., Lovett, G.M., Mohan, J., Orwig, D.A., Rodenhouse, N.L., Sobczak, W.V., Stinson, K.A., Stone, J.K., Swan, C.M., Thompson, J., Von Holle, B., Webster, J.R., 2005. Loss of foundation species: consequences for the structure and dynamics of forested ecosystems. Frontiers in Ecology and the Environment 3, 479-486. DOI: $10.2307 / 3868635$. 
Andersen, D.C. - Narrowleaf cottonwood ecohydrology

Emery, P.A., Boettcher, A.J., Snipes, R.J., McIntyre, H.J., 1971. Hydrology of the San Luis Valley, south-central Colorado. U.S. Geological Survey Hydrologic Investigations Atlas HA-381. U. S. Geological Survey, Washington, D. C.

Gom, L.A., Rood, S.B., 1999. Patterns of clonal occurrence in a mature cottonwood grove along the Oldman River, Alberta. Canadian Journal of Botany 77, 1095-1105.

Gribovszki, Z., Szilagyi, J., Kalicz, P., 2010. Diurnal fluctuations in shallow groundwater levels and streamflow rates and their interpretation - a review. Journal of Hydrology 385, 371-383. DOI:10.1016/j.jhydrol.2010.02.001

Grissino-Mayer, H.D., 2001. Evaluating crossdating accuracy: a manual and tutorial for the computer program COFECHA. Tree-Ring Research 57, 205-221.

Hadlock, G.L., Lachmar, T.E., McCalpin, J.P., 1997. The relationship between the water table and the surface flow of a losing stream, lower Medano Creek, Great Sand Dunes National Monument, Colorado. Environmental Geology 30, 10-16.

Harte, J.J., Valdez, A.D., Stevenson, S.A., 2007. Seepage investigation of Deadman Creek, Sand Creek, Big Spring Creek, and Little Spring Creek, September 22, 23, and 24, 2004, Great Sand Dunes National Park and Preserve Colorado. Natural Resource Technical Report NPS/NRPC/WRD/NRTR-2007/071. National Park Service, Fort Collins, Colorado.

Henz, J., Turner, S., Badini, W., Kenny, J., 2004. Historical perspectives on Colorado drought. Colorado Water Conservation Board. Available online: http://cwcb.state.co.us/apps/drought_water/html/chapter01.html (accessed 29 April 2013). Board, C.W.C.

Ishihama, F., Fujii, S., Yamamoto, K., Takada, T., 2014. Estimation of dieback process caused by herbivory in an endangered root-sprouting shrub species, Paliurus ramosissimus (Lour.) Poir., using a shoot-dynamics matrix model. Population Ecology 56, 275-288. DOI: 10.1007/s 10144-013-0414-1.

Johnson, R.B., 1967. The Great Sand Dunes of southern Colorado. U.S. Geological Survey Professional Paper 575-C, C177-C183. U. S. Geological Survey, Washington, D. C. Kennard, M.J., Mackay, S.J., Pusey, B.J., Olden, J.D., Marsh, N., 2010. Quantifying uncertainty in estimation of hydrologic metrics for ecohydrological studies. River Research and Applications 26, 137-156. DOI: 10.1002/rra.1249 
Andersen, D.C. - Narrowleaf cottonwood ecohydrology

Levick, L., Fonseca, J., Goodrich, D., Hernandez, M., Semmens, D., Stromberg, J., Leidy, R., Scianni, M., Guertin, D.P., Tluczek, M., Kepner, W., 2008. The ecological and hydrological significance of ephemeral and intermittent streams in the arid and semi-arid American Southwest. U.S. Environmental Protection Agency and USDA/ARS Southwest Watershed Research Center. EPA/600/R-08/134, ARS/233046. Environmental Protection Agency, Washington, D. C.

Mayo, A.L., Davey, A., Christiansen, D., 2007. Groundwater flow patterns in the San Luis Valley, Colorado, USA revisited: an evaluation of solute and isotopic data. Hydrogeology Journal 15, 383-408. DOI: 10.1007/s10040-006-0079-3

Meko, D.M., Friedman, J.M., Touchan, R., Edmondson, J.R., Griffin, E.R., Scott, J.A., 2015. Alternative standardization approaches to improving streamflow reconstructions with ring-width indices of riparian trees. The Holocene 25, 1093-1101. DOI: $10.1177 / 0959683615580181$.

Mix, K., Lopes, V.L., Rast, W., 2011. Annual and growing season temperature changes in the San Luis Valley, Colorado. Water Air and Soil Pollution 220, 189-203. DOI: 10.1007/s11270-011-0746-4.

Nielsen, J.L., Rood, S.B., Pearce, D.W., Letts, M.G., Jiskoot, H., 2010. Streamside trees: responses of male, female and hybrid cottonwoods to flooding. Tree Physiology 30, 14791488. DOI: 10.1093/treephys/tpq089.

Obedzinski, R.A., Shaw, C.G., III, Neary, D.G., 2001. Declining woody vegetation in riparian ecosystems of the western United States. Western Journal of Applied Forestry 16, 169-181.

Palmer, W.C., 1965. Meterological drought. U. S. Weather Bureau, Office of Climatology Research Paper 45. Washington, D. C.

Peltzer, D.A., 2002. Does clonal integration improve competitive ability? A test using aspen (Populus tremuloides Salicaceae ) invasion into prairie. American Journal of Botany 89, 494-499. DOI: 10.3732/ajb.89.3.494.

Perry, L.G., Andersen, D.C., Reynolds, L.V., Nelson, S.M., Shafroth, P.B., 2012. Vulnerability of riparian ecosystems to elevated $\mathrm{CO}_{2}$ and climate change in arid and semiarid western North America. Global Change Biology 18, 821-842. DOI: 10.1111/j.13652486.2011.02588.x. 
Andersen, D.C. - Narrowleaf cottonwood ecohydrology

826 Pregitzer, K.S., Friend, A.L., 1996. The structure and function of Populus root systems, in:

Stettler, R.F., Bradshaw, H.D., Jr., Heilman, P.E., Hinckley, T.M. (Eds.), Biology of Populus and its implications for management and conservation. NRC Research Press, Ottawa, Canada, pp. 331-354.

Reclamation, Bureau of, 2003. Relocation of Salvage Wells, Closed Basin Division, San Luis Basin Project, Colorado. Finding of no significant impact and environmental assessment. Biological Assessment. Final. Albuquerque Area Office, Upper Colorado Region. Albuquerque, New Mexico.

Rood, S., Bigelow, S., Hall, A., 2011. Root architecture of riparian trees: river cut-banks provide natural hydraulic excavation, revealing that cottonwoods are facultative phreatophytes. Trees-Structure and Function 25, 907-917. DOI: 10.1007/s00468-011-0565-7.

Rood, S.B., Ball, D.J., Gill, K.M., Kaluthota, S., Letts, M.G., Pearce, D.W., 2013. Hydrologic linkages between a climate oscillation, river flows, growth, and wood $\Delta^{13} \mathrm{C}$ of male and female cottonwood trees. Plant, Cell \& Environment 36, 984-993. DOI: 10.1111/pce.12031. Rood, S.B., Nielsen, J.L., Shenton, L., Gill, K.M., Letts, M.G., 2010. Effects of flooding on leaf development, transpiration, and photosynthesis in narrowleaf cottonwood, a willow-like poplar. Photosynthesis Research 104, 31-39. DOI: 10.1007/s11120-009-9511-6.

Rood, S.B., Patiño, S., Coombs, K., Tyree, M.T., 2000. Branch sacrifice: Cavitation-associated drought adaptation of riparian cottonwoods. Trees-Structure and Function 14, 248-257.

Rood, S.B., Samuelson, G.M., Braatne, J.H., Gourley, C.R., Hughes, F.M.R., Mahoney, J.M., 2005. Managing river flows to restore floodplain forests. Frontiers in Ecology and the Environment 3, 193-201. DOI: 10.1890/1540-9295(2005)003[0193:MRFTRF]2.0.CO;2.

Schoenecker, K.A., 2012. Ecology of bison, elk, and vegetation in an arid ecosystem, PhD. Dissertation. Colorado State University, Fort Collins, Colorado.

Scott, M.L., Lines, G.C., Auble, G.T., 2000. Channel incision and patterns of cottonwood stress and mortality along the Mojave River, California. Journal of Arid Environments 44, 399414.

Scott, M.L., Shafroth, P.B., Auble, G.T., 1999. Responses of riparian cottonwoods to alluvial water table declines. Environmental Management 23, 347-358.

Shafroth, P.B., Stromberg, J.C., Patten, D.T., 2000. Woody riparian vegetation response to different alluvial water table regimes. Western North American Naturalist 60, 66-76. 
Andersen, D.C. - Narrowleaf cottonwood ecohydrology

857

Shafroth, P.B., Wilcox, A.C., Lytle, D.A., Hickey, J.T., Andersen, D.C., Beauchamp, V.B., Hautzinger, A., McMullen, L.E., Warner, A., 2010. Ecosystem effects of environmental flows: modelling and experimental floods in a dryland river. Freshwater Biology 55, 68-85. DOI: 10.1111/j.1365-2427.2009.02271.x

Soykan, C.U., Brand, L.A., Ries, L., Stromberg, J.C., Hass, C., Simmons, D.A., Jr., Patterson, W.J.D., Sabo, J.L., 2012. Multitaxonomic diversity patterns along a desert riparian-upland gradient. PLoS ONE 7, e28235. DOI: 10.1371/journal.pone.0028235.

Stromberg, J.C., Merritt, D.M., 2015. Riparian plant guilds of ephemeral, intermittent and perennial rivers. Freshwater Biology, n/a-n/a. DOI: 10.1111/fwb.12686.

Tockner, K., Stanford, J.A., 2002. Riverine flood plains: present state and future trends. Environmental Conservation 29, 308-330. DOI: 10.1017/S037689290200022X.

Wiehle, M., Eusemann, P., Thevs, N., Schnittler, M., 2009. Root suckering patterns in Populus euphratica (Euphrates poplar, Salicaceae). Trees-Structure and Function 23, 991-1001. DOI: 10.1007/s00468-009-0341-0.

Willms, C.R., Pearce, D.W., Rood, S.B., 2006. Growth of riparian cottonwoods: a developmental pattern and the influence of geomorphic context. Trees-Structure and Function 20, 210-218. DOI: $10.1007 / \mathrm{s} 00468-005-0027-1$.

Wurster, F.C., Cooper, D.J., Sanford, W.E., 2003. Stream/aquifer interactions at Great Sand Dunes National Monument, Colorado: influences on interdunal wetland disappearance. Journal of Hydrology 271, 77-100. DOI: 10.1016/S0022-1694(02)00317-7.

Yamaguchi, D.K., 1991. A simple method for cross-dating increment cores from living trees. Canadian Journal of Forest Research 21, 414-416. DOI: 10.1139/x91-053. 
Andersen, D.C. - Narrowleaf cottonwood ecohydrology

Table 1. Sites along Sand and Deadman creeks where relationships between Fremont cottonwood radial growth and local hydrologic

881 conditions were investigated.

\begin{tabular}{|c|c|c|c|c|c|c|c|}
\hline $\begin{array}{c}\text { Site } \\
\text { (altitude, m) }\end{array}$ & \multicolumn{3}{|c|}{ Stream } & Floodplain soil texture & \multicolumn{3}{|c|}{ Observation wells } \\
\hline $\mathrm{S} 2(\sim 2414)$ & Unconfined & Perennial? & Unincised & $\begin{array}{l}\text { Variably thin }(<1 \mathrm{~m} \text { to } \sim 2.5 \\
\text { m) sands over cobble }\end{array}$ & None & & --- \\
\hline S4 ( 2316) & Unconfined & Ephemeral & Unincised & Thick sands & 12 & $\begin{array}{l}\text { SW-1 to } \\
\text { SW12 }\end{array}$ & $\begin{array}{l}\text { October } 2006 \text { to } \\
\text { September } 2008 \#\end{array}$ \\
\hline $\mathrm{D} 1(\sim 2377)$ & Unconfined & Perennial? & Unincised & $\begin{array}{l}\text { Sand and silt }(<1 \mathrm{~m}) \text { over } \\
\text { cobble }\end{array}$ & None & & --- \\
\hline $\mathrm{D} 2(\sim 2327)$ & Unconfined & Ephemeral? & Incised & $\begin{array}{l}\text { Thick sands with a } 5-\mathrm{cm} \\
\text { thick clay lens at } 1.5-\mathrm{m} \text { depth }\end{array}$ & 1 & DW1 & $\begin{array}{l}1 \text { Dec } 2010 \text { through } \\
\text { May } 2012 * *\end{array}$ \\
\hline
\end{tabular}

$\dagger$ The segment of Sand Creek containing S1, S2 and S3 transects the major transverse dune field of Great Sand Dunes National Park and passes through an area featuring fixed parabolic and active parabolic dunes of accumulation (Johnson, 1967).

tObserved during installation of hand-augered observation wells; shallow cobble precluded well installation at sites S1, S2, S3, and D1.

\# S4 groundwater levels during the 2007 growing season were monitored manually every few weeks (9 wells) or at 3-hr intervals using vented water-level loggers (GlobalWater Model WL15; wells SW1, SW2 and SW3). Wells were monitored manually on a sporadic basis during the 2008 growing season.

**Groundwater level at sites D2 and D4 were monitored continuously using unvented Onset® Hobo U20-001-04 pressure sensor/loggers and an associated non-submerged sensor recording local barometric pressures for compensation calculations. 
Andersen, D.C. - Narrowleaf cottonwood ecohydrology

891 Table 2. Hydrologic and meteorological variables assessed for their effect on radial growth of Fremont cottonwood present on the 892 floodplains of Sand and Deadman creeks in Great Sand Dunes National Park. Both current and previous year values were assessed for 893 the two discharge variables, PDSIs, and Ps, thus producing a total of 15 variables.

\begin{tabular}{|c|c|c|c|c|}
\hline \multirow[t]{2}{*}{ Symbol } & \multirow[t]{2}{*}{ Environmental variable } & \multirow[t]{2}{*}{ Definition } & \multicolumn{2}{|c|}{ Data period } \\
\hline & & & Sand Creek & Deadman $\mathrm{Cr}$ \\
\hline QM3 & Maximum 3-day discharge & During 1 May to 15 July & $1994-2007$ & $1999-2010$ \\
\hline QM30 & Maximum 30-day discharge & During 1 May to 15 July & 1994-2007 & $1999-2010$ \\
\hline $\mathrm{P}_{\mathrm{W}}$ & $\begin{array}{l}\text { Late winter \& spring } \\
\text { precipitation }\end{array}$ & Total precipitation January through May & $1951-2007$ & $1951-2007$ \\
\hline $\mathrm{P}_{\mathrm{S}}$ & Summer precipitation & Total precipitation June through August & $1951-2007$ & $1951-2007$ \\
\hline PSMAX & $\begin{array}{l}\text { Maximum total monthly } \\
\text { summer precipitation }\end{array}$ & $\begin{array}{l}\text { Maximum monthly precipitation among June, July } \\
\text { and August }\end{array}$ & $1951-2007$ & $1951-2007$ \\
\hline P SMIN $_{1}$ & $\begin{array}{l}\text { Minimum total monthly } \\
\text { precipitation }\end{array}$ & $\begin{array}{l}\text { Minimum monthly precipitation among June, July, } \\
\text { August and September }\end{array}$ & $1951-2007$ & $1951-2007$ \\
\hline TMAR & Mean March air temperature & & $1951-2007$ & $1951-2007$ \\
\hline $\mathrm{T}_{\mathrm{APR}}$ & Mean April air temperature & & $1951-2007$ & $1951-2007$ \\
\hline TMAY & Mean May air temperature & & $1951-2007$ & $1951-2007$ \\
\hline TuUN & Mean June air temperature & & $1951-2007$ & $1951-2007$ \\
\hline PDSIs & $\begin{array}{l}\text { Seasonal Palmer Drought } \\
\text { Severity Index }\end{array}$ & Mean of January through July monthly PDSI values & $1900-2007$ & $1900-2010$ \\
\hline
\end{tabular}

894 
Andersen, D.C. - Narrowleaf cottonwood ecohydrology

896

897 Table 3. Pearson correlation matrix for 15 environmental variables considered in assessment of hydrologic factors affecting growth 898 of floodplain narrowleaf cottonwood along Sand Creek ( $n=14$ years, 1994-2007). Variable abbreviations are defined in Table 2.

899 Values in bold text are $\geq 0.70$.

\begin{tabular}{|c|c|c|c|c|c|c|c|c|c|c|c|c|c|c|c|}
\hline & $\mathrm{PDSI}_{\mathrm{S}}$ & PYPDSI $_{S}$ & $P_{\mathrm{W}}$ & $\overline{\mathrm{P}_{\mathrm{S}}}$ & $\mathrm{PYP}_{\mathrm{S}}$ & 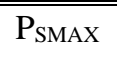 & $\mathrm{P}_{\mathrm{SMIN}}$ & $\mathrm{Q}_{\mathrm{M} 3}$ & $\mathrm{PYQ}_{\mathrm{M} 3}$ & $\mathrm{Q}_{\mathrm{M} 30}$ & $\mathrm{PYQ}_{\mathrm{M} 30}$ & $\mathrm{~T}_{\mathrm{MAR}}$ & $\mathrm{T}_{\mathrm{APR}}$ & $\mathrm{T}_{\mathrm{MAY}}$ & $\mathrm{T}_{\mathrm{JUN}}$ \\
\hline $\mathrm{PDSI}_{\mathrm{S}}$ & 1.00 & & & & & & & & & & & & & & \\
\hline $\mathrm{PYPDSI}_{\mathrm{S}}$ & 0.69 & 1.00 & & & & & & & & & & & & & \\
\hline $\mathrm{P}_{\mathrm{W}}$ & 0.45 & -0.05 & 1.00 & & & & & & & & & & & & \\
\hline $\mathrm{P}_{\mathrm{S}}$ & 0.35 & -0.12 & 0.38 & 1.00 & & & & & & & & & & & \\
\hline PYPS $_{S}$ & 0.48 & 0.44 & -0.17 & 0.20 & 1.00 & & & & & & & & & & \\
\hline$P_{\text {SMAX }}$ & 0.32 & -0.14 & 0.42 & 0.82 & 0.40 & 1.00 & & & & & & & & & \\
\hline$P_{\text {SMIN }}$ & 0.18 & -0.003 & 0.22 & 0.47 & -0.17 & -0.02 & 1.00 & & & & & & & & \\
\hline $\mathrm{Q}_{\mathrm{M} 3}$ & 0.15 & -0.34 & 0.46 & 0.46 & -0.32 & 0.25 & 0.38 & 1.00 & & & & & & & \\
\hline $\mathrm{PYQ}_{\mathrm{M} 3}$ & 0.02 & 0.11 & -0.40 & 0.29 & 0.54 & 0.46 & -0.22 & -0.23 & 1.00 & & & & & & \\
\hline $\mathrm{Q}_{\mathrm{M} 30}$ & 0.50 & -0.05 & 0.77 & 0.47 & -0.11 & 0.42 & 0.20 & 0.78 & -0.21 & 1.00 & & & & & \\
\hline $\mathrm{PYQ}_{\mathrm{M} 30}$ & 0.22 & 0.54 & -0.28 & -0.03 & 0.49 & 0.10 & -0.13 & -0.35 & 0.76 & -0.26 & 1.00 & & & & \\
\hline $\mathrm{T}_{\mathrm{MAR}}$ & 0.17 & -0.16 & 0.52 & 0.41 & 0.01 & 0.36 & 0.39 & -0.09 & 0.02 & 0.08 & 0.03 & 1.00 & & & \\
\hline $\mathrm{T}_{\mathrm{APR}}$ & -0.46 & 0.04 & -0.67 & -0.57 & -0.24 & -0.61 & -0.38 & -0.49 & -0.15 & -0.70 & -0.10 & -0.36 & 1.00 & & \\
\hline $\mathrm{T}_{\mathrm{MAY}}$ & -0.49 & -0.04 & -0.64 & -0.47 & 0.03 & -0.32 & -0.35 & -0.46 & 0.16 & -0.77 & 0.19 & -0.36 & 0.56 & 1.00 & \\
\hline$T_{\text {JUN }}$ & -0.28 & 0.17 & -0.59 & -0.26 & 0.10 & -0.19 & -0.33 & -0.43 & 0.21 & -0.63 & 0.22 & -0.24 & 0.72 & 0.54 & 1.00 \\
\hline
\end{tabular}

900 
Table 4. Qualitative results of stepwise-forward multiple regression analysis relating narrowleaf cottonwood annual standardized growth index (SGI) values to recent streamflow and climate variables over the length of the streamflow record, and to solely climate variables over the longest period possible (determined by SGI series length). Analyses are for Sand Creek (S) and Deadman Creek (D) tree groups classified as "near to" or "far from" the stream channel (see text for full details). Mean depth to the water table under the analyzed trees is an estimate for October 2007. $N=$ number of trees contributing to the SGI series used in the recent-years analysis; the number of contributing trees in the longest-period analysis declined as the SGI series lengthened, but was never less than three. $P($ entry $)=P($ remove $)=0.15$ unless otherwise noted. Final model probability: $*=<0.05, * *=\leq 0.01, * * *=\leq 0.001$. The number of years of data in the analysis (n) was 13-14 for all Sand Creek and 11-12 for all Deadman Creek recent-year analyses. The first variable entered into the model is indicated with bold font; the sign (positive or negative) indicates the direct or inverse nature of the

910 relationship.

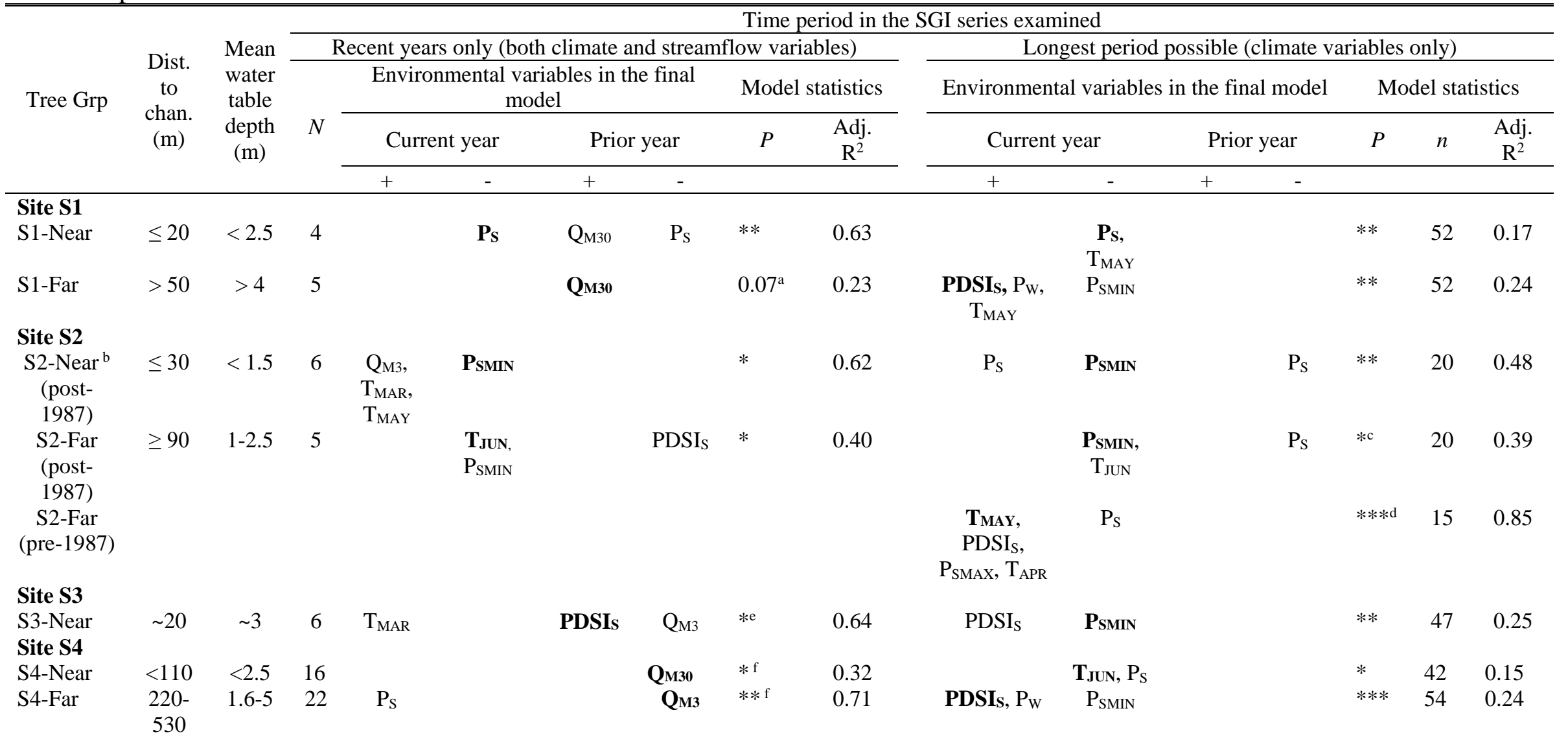


Andersen, D.C. - Narrowleaf cottonwood ecohydrology

\begin{tabular}{|c|c|c|c|c|c|c|c|c|c|c|c|c|c|c|c|c|}
\hline Site D1 & & & & & & & & & & & & & & & & \\
\hline $\begin{array}{l}\text { D1-Near } \\
\text { Site D2 }\end{array}$ & $\sim 20$ & $<2$ & 1 & & $\mathrm{P}_{\text {SMIN }}$ & & PDSIs & $*$ & 0.40 & & & & & & & \\
\hline D2-Near & $<20$ & $\sim 1.75$ & 4 & $\mathbf{T}_{\text {MaY }}$ & & & & $* \mathrm{~g}$ & 0.33 & $\mathrm{~T}_{\mathrm{MAR}}, \mathrm{T}_{\mathrm{MAY}}$ & & & PDSIs & $* *$ & 36 & 0.29 \\
\hline D2-Far & $>120$ & $\geq 2.75$ & 6 & & & $\mathrm{Q}_{\mathrm{M} 3}$ & Qм30 & 0.052 & 0.40 & $\begin{array}{c}\text { PDSI }_{S} \\
\mathrm{~T}_{\mathrm{APR}}\end{array}$ & $\begin{array}{c}\text { PSMIN } \\
\text { T }_{\text {JUN }}\end{array}$ & & & $*$ & 32 & 0.23 \\
\hline Site D3 & & & & & & & & & & & & & & & & \\
\hline D3-Far & $>160$ & $\geq 3$ & 9 & & $\begin{array}{c}\text { P }_{\text {SMIN }}, \\
\text { T }_{\text {MAY }}\end{array}$ & & $\mathrm{Q}_{\mathrm{M} 30}$ & $* *$ & 0.69 & $\begin{array}{l}\mathbf{T}_{\mathrm{APR}}, \\
\text { PDSIS }_{\mathrm{S}}\end{array}$ & & & $\mathrm{PDSI}_{\mathrm{S}}$ & $*$ & 37 & 0.22 \\
\hline $\begin{array}{l}\text { Site D4 } \\
\text { D4-Near }\end{array}$ & $<20$ & $>1.5$ & 3 & Ps & & & Ps & $* \mathrm{~h}$ & 0.42 & Psmax & $\begin{array}{c}\mathrm{P}_{\mathrm{W}}, \\
\mathrm{P}_{\text {SMIN }}\end{array}$ & PDSI $_{\mathrm{S}}$ & $\mathbf{P s}_{\mathrm{s}}$ & $* \mathrm{i}$ & 21 & 0.41 \\
\hline
\end{tabular}

$911 \quad{ }^{2}$ Model is for dataset excluding 1996; no model resulted using the full dataset.

$912{ }^{\mathrm{b}} P($ enter $)=P($ Remove $)=0.10$ for Stage 1 analysis; single D1-Near tree and six S2-Near trees pooled for Stage 2 analysis.

913 "S2-Far "longest period" data are limited to years post-1987.

914 "S2-Far "longest period" data are limited to years pre-1988.

915 e Model is for dataset excluding 1996 and 1997; no model was produced using the full dataset, exclusion of solely 1997, or exclusion 916 of 1997 and 2003.

917 f Model is for dataset excluding 1997; no model resulted using the full dataset.

$918 \mathrm{~g}$ Model is for dataset excluding 1999; no model resulted using the full dataset.

919 hodel is for dataset excluding 1997 and 2003; no model resulted using the full dataset or excluding solely 1997.

920 i Model is for dataset excluding 1997, 2002, and 2003; no model resulted using the full data set or excluding only 1997 and 2003. 
Andersen, D.C. - Narrowleaf cottonwood ecohydrology

Table 5. Group statistics for the standardized growth index (SGI) series for tree groups output from the tree-ring analysis program COFECHA and mean SGI values for five years with unusually dry (1981, 1996, and 2002), wet (1987), or cold (1995) conditions during the growing season.

\begin{tabular}{|c|c|c|c|c|c|c|c|c|c|c|c|c|}
\hline \multirow{2}{*}{ Creek } & \multirow{2}{*}{ Site } & \multirow{2}{*}{ Tree group } & \multirow{2}{*}{$\begin{array}{l}\text { Number } \\
\text { of trees }\end{array}$} & \multirow{2}{*}{$\begin{array}{c}\text { Longest } \\
\text { series } \\
(\mathrm{yr})\end{array}$} & \multirow{2}{*}{$\begin{array}{c}\text { Mean } \\
\text { series } \\
\text { length }(y r)\end{array}$} & \multirow{2}{*}{$\begin{array}{l}\text { Interseries } \\
\text { correlation }\end{array}$} & \multirow{2}{*}{$\begin{array}{c}\text { Average } \\
\text { mean } \\
\text { sensitivity }\end{array}$} & \multicolumn{5}{|c|}{ Mean SGI } \\
\hline & & & & & & & & 1981 & 1987 & 1995 & 1996 & 2002 \\
\hline \multirow[t]{7}{*}{ Sand } & S1 & Near & 4 & 53 & 53 & 0.01 & 0.32 & 1.34 & 1.26 & 0.95 & 1.01 & 1.19 \\
\hline & & Far & 5 & 53 & 53 & 0.20 & 0.27 & 0.62 & 1.67 & 1.02 & 0.84 & 0.74 \\
\hline & $\mathrm{S} 2$ & Near $^{\mathrm{a}}$ & 7 & 56 & 31 & $0.38^{\mathrm{b}}$ & 0.32 & 0.99 & 0.85 & 0.73 & 0.62 & 0.63 \\
\hline & & Far & 6 & 56 & 42 & 0.13 & 0.34 & 0.84 & 1.26 & 0.87 & 0.82 & 0.61 \\
\hline & S3 & Near & 6 & 70 & 54 & 0.25 & 0.25 & 0.77 & 1.17 & 1.00 & 0.55 & 1.00 \\
\hline & $\mathrm{S} 4$ & Near & 16 & 85 & 33 & 0.46 & 0.27 & 0.54 & 1.08 & 0.88 & 0.58 & 0.91 \\
\hline & & Far & 22 & 86 & 45 & $0.36^{c}$ & 0.24 & 0.82 & 1.19 & 1.01 & 0.80 & 0.87 \\
\hline \multirow[t]{4}{*}{ Deadman } & D2 & Near & 4 & 67 & 50 & 0.02 & 0.21 & 0.89 & 0.74 & 0.80 & 0.88 & 1.14 \\
\hline & & Far & 6 & 39 & 31 & 0.41 & 0.19 & --- & 1.11 & 0.85 & 0.63 & 1.07 \\
\hline & D3 & Far & 9 & 73 & 48 & 0.36 & 0.22 & 0.95 & 1.21 & 0.66 & 0.74 & 1.05 \\
\hline & D4 & Near & 3 & 32 & 29 & 0.32 & 0.30 & --- & 1.28 & 0.92 & 1.05 & 0.53 \\
\hline
\end{tabular}

927 "Exclusion of two "contrary" trees raises the interseries correlation to 0.43 
Andersen, D.C. - Narrowleaf cottonwood ecohydrology

Table 6. Results of sequential comparisons of multiple regression analyses to link narrowleaf cottonwood growth to environmental variables with and without candidate legacy years 1982, 1997, and 2003 in the analyzed dataset.

\begin{tabular}{|c|c|c|c|c|c|c|c|c|}
\hline \multirow{3}{*}{ Site } & \multirow{3}{*}{ Tree group } & \multicolumn{3}{|c|}{ Stage 1 analyses } & \multicolumn{4}{|c|}{ Stage 2 analyses } \\
\hline & & \multirow{2}{*}{$\begin{array}{l}\text { Was a model } \\
\text { produced? }\end{array}$} & \multicolumn{2}{|c|}{$\begin{array}{l}\text { Was model produced or } \mathrm{R}^{2} \\
\text { increased by exclusion of... }\end{array}$} & \multirow{2}{*}{$\begin{array}{l}\text { Was a model } \\
\text { produced? }\end{array}$} & \multicolumn{3}{|c|}{$\begin{array}{l}\text { Was model produced or } \mathrm{R}^{2} \\
\text { increased by exclusion of... }\end{array}$} \\
\hline & & & 1997 & 2003 & & 1982 & 1997 & 2003 \\
\hline \multirow[t]{2}{*}{ D2 } & D2-Near & No & $\begin{array}{ll}-- \\
-1\end{array}$ & No & Yes & Yes & No & No \\
\hline & D2-Far & Yes & --- & No & Yes & No & No & Yes \\
\hline D3 & D3-Far & Yes & --- & No & Yes & No & No & No \\
\hline \multirow[t]{2}{*}{$\mathrm{S} 1$} & S1-Near & Yes & Yes & Yes & Yes & No & No & No \\
\hline & S1-Far & No & No & No & Yes & No & No & No \\
\hline \multirow[t]{2}{*}{$\mathrm{S} 2$} & S2-Near post-1987 ${ }^{\mathrm{a}}$ & Yes & Yes & No & Yes & --- & No & No \\
\hline & S2-Far post-1987 & Yes & Yes & No & Yes & --- & No & Yes \\
\hline S3 & S3-Near & No & No & No & Yes & No & No & Yes \\
\hline \multirow[t]{2}{*}{$\mathrm{S} 4$} & S4-Near & No & Yes & No & Yes & No & No & Yes \\
\hline & S4-Far & No & Yes & No & Yes & No & Yes & Yes \\
\hline
\end{tabular}

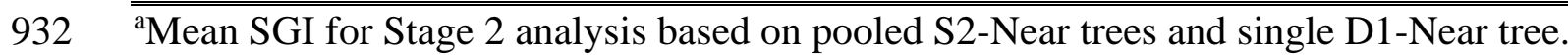


Andersen, D.C. - Narrowleaf cottonwood ecohydrology

934 Table 7. Results of sequential ANOVAs testing for an effect from Closed Basin Project 935 groundwater pumping on annual growth (mean SGI) in tree groups far from the Sand Creek 936 channel, with annual climate index PDSIs as a covariate. Groups S4-LOW, -MID and -HIGH 937 were separately tested. "Pumping" is a categorical variable with value "No" for years before 938 1986, when Stage 3 pumping began, and "Yes" for years 1986 and after. The number of years of 939 pre-pumping SGI values varied among the groups, hence the differences in error degrees of 940 freedom. (A) The first ANOVA tests for differences in slope. The interaction term 941 "Pumping*PDSIs" tests the null hypothesis that slopes of the regressions of SGI on PDSIs before 942 and after pumping began are equal. (B) Given the result of no statistical difference in the two 943 slopes for any group, the second ANOVA tests the null hypothesis, via the term Pumping, that 944 the intercepts of the parallel regression lines are equal.

\begin{tabular}{|c|c|c|c|c|c|c|c|}
\hline Analysis & $\begin{array}{l}\text { Tree } \\
\text { group }\end{array}$ & Source & $\begin{array}{l}\text { Sum of } \\
\text { squares }\end{array}$ & $d f$ & $\begin{array}{l}\text { Mean- } \\
\text { square }\end{array}$ & $F$-ratio & $P$ \\
\hline \multirow[t]{12}{*}{ A } & \multirow[t]{4}{*}{ LOW } & PDSIs & 0.373 & 1 & 0.373 & 16.495 & $<0.001$ \\
\hline & & Pumping & 0.005 & 1 & 0.005 & 0.228 & 0.636 \\
\hline & & Pumping*PDSIs & 0.032 & 1 & 0.032 & 1.418 & 0.243 \\
\hline & & Error & 0.679 & 30 & 0.023 & & \\
\hline & \multirow[t]{4}{*}{ MED } & $\mathrm{PDSI}_{\mathrm{S}}$ & 0.315 & 1 & 0.315 & 12.627 & 0.001 \\
\hline & & Pumping & 0.001 & 1 & 0.001 & 0.020 & 0.887 \\
\hline & & Pumping*PDSIs & 0.065 & 1 & 0.065 & 2.622 & 0.117 \\
\hline & & Error & 0.648 & 26 & 0.025 & & \\
\hline & \multirow[t]{4}{*}{ HIGH } & $\mathrm{PDSI}_{\mathrm{S}}$ & 0.066 & 1 & 0.066 & 3.282 & 0.078 \\
\hline & & Pumping & 0.051 & 1 & 0.051 & 2.554 & 0.118 \\
\hline & & Pumping*PDSIs & 0.006 & 1 & 0.006 & 0.311 & 0.580 \\
\hline & & Error & 0.762 & 38 & 0.020 & & \\
\hline \multirow[t]{9}{*}{ B } & \multirow[t]{3}{*}{ LOW } & PDSIs & 0.364 & 1 & 0.364 & 15.876 & 0.000 \\
\hline & & Pumping & 0.000 & 1 & 0.000 & 0.002 & 0.963 \\
\hline & & Error & 0.711 & 31 & 0.023 & & \\
\hline & \multirow[t]{3}{*}{ MED } & PDSIS $_{S}$ & 0.257 & 1 & 0.257 & 9.720 & 0.004 \\
\hline & & Pumping & 0.026 & 1 & 0.026 & 0.970 & 0.333 \\
\hline & & Error & 0.714 & 27 & 0.026 & & \\
\hline & \multirow[t]{3}{*}{ HIGH } & $\mathrm{PDSI}_{\mathrm{S}}$ & 0.061 & 1 & 0.061 & 3.086 & 0.087 \\
\hline & & Pumping & 0.081 & 1 & 0.081 & 4.108 & 0.050 \\
\hline & & Error & 0.768 & 39 & 0.020 & & \\
\hline
\end{tabular}

945

946 
Andersen, D.C. - Narrowleaf cottonwood ecohydrology

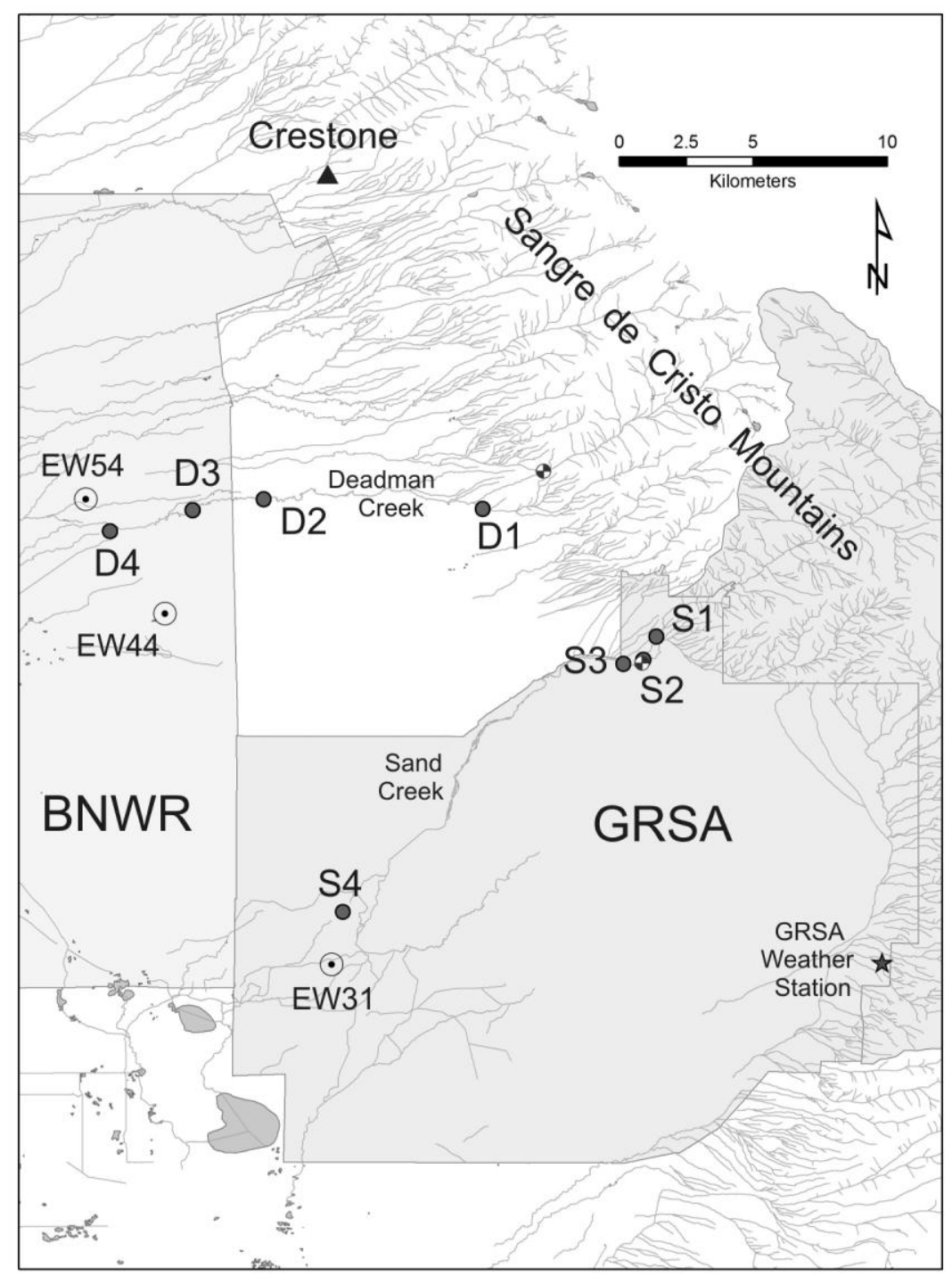

948 Figure 1. Map of the study area within the Baca National Wildlife Refuge (BNWR) and Great 949 Sand Dunes National Park (GRSA) and adjacent Preserve, near Crestone, Colorado, showing 950 drainage channels on the west slope of the Sangre de Cristo Mountains and the location of the 951 four study sites along each of Sand and Deadman creeks (S1-S4 and D1-D4, respectively). 952 Stream gauge locations are shown with the quarter-filled circles. The locations of the Closed 953 Basin Project (CBP) monitoring wells (EW31, EW44, and EW54) closest to the study sites are 954 also shown. The closest CBP groundwater extraction wells are located $\sim 4 \mathrm{~km}$ west of the map 955 boundary.

956 


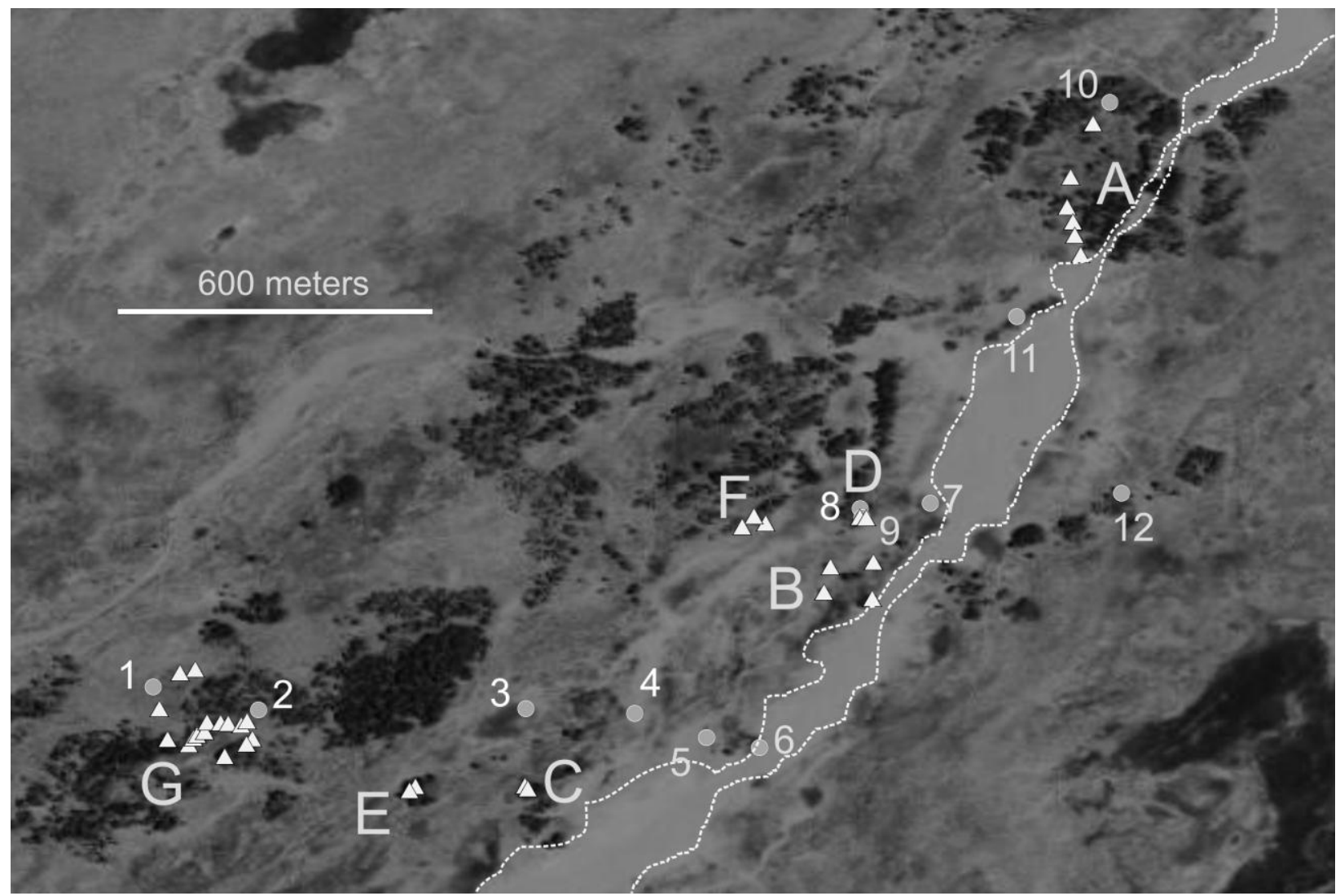

959 Figure 2. Lower Sand Creek study site S4 showing the approximate locations of the 2007 active

960 channel margins (dashed lines) and the locations of observation wells SW1 to SW12 (numbered

961 circles) and the narrowleaf cottonwood trees cored for radial growth analysis (triangles). Letters

962 (A-G) identify separate landforms and tree clusters sampled; not all individual trees are shown.

963 Group S4-Far was made up of trees in clusters E, F, and G; all other trees were in Group S4-

964 Near. North is to the top of the image. Anecdotal evidence suggests that ranch management

965 activities prior to 2006 included periodic diversion of Sand Creek flows at a point in the channel

966 near or above tree group A. Imagery is from ArcGIS World Imagery (acquisition date is

967 probably October 2011). World Imagery sources: ESRI, DigitalGlobe, GeoEye, Earthstar

968 Geographics, CNES/Airbus DS, USDA, USGS, AEX, Getmapping, Aerogrid, IGN, IGP,

969 swisstopo, and the GIS User Community. 
Andersen, D.C. - Narrowleaf cottonwood ecohydrology

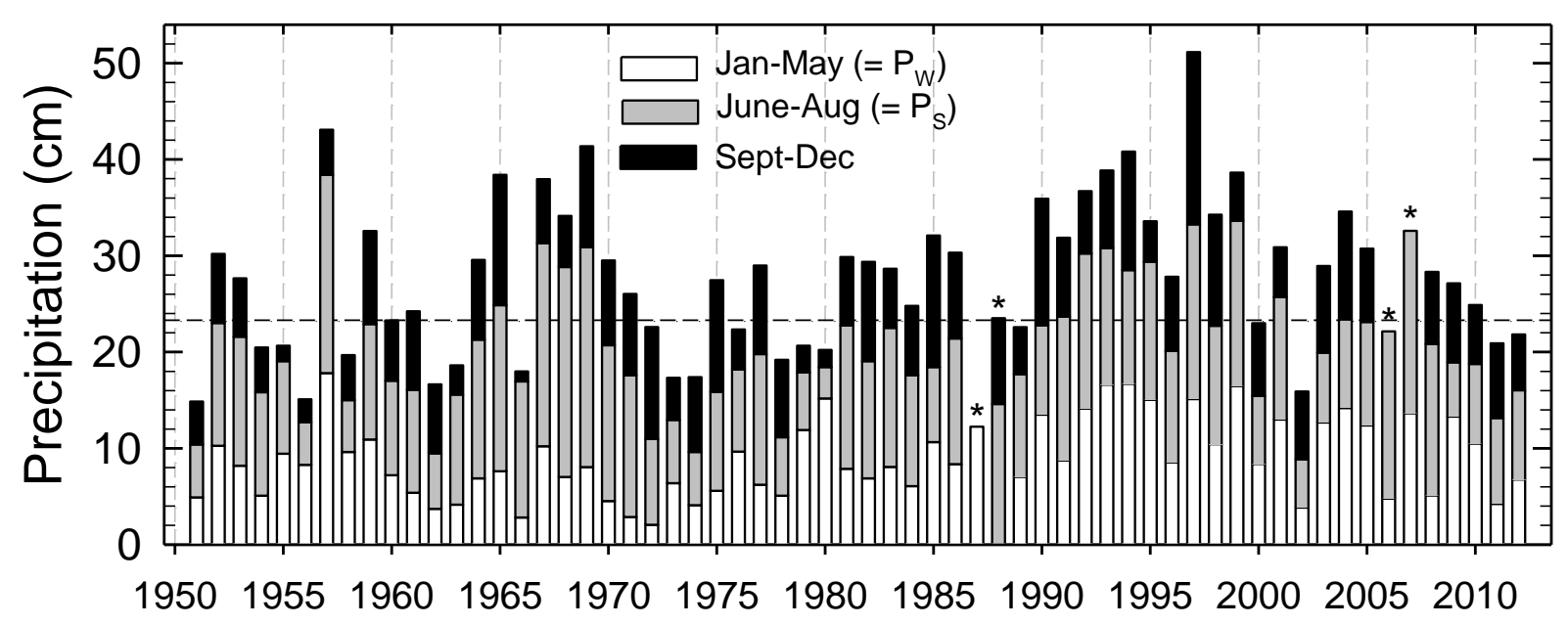

971

973 Figure 3. Stacked bar graph depicting seasonal precipitation values calculated from monthly

974 totals at National Weather Service station Great Sand Dunes National Monument (053541). The

975 height of each column is the total annual precipitation. The horizontal dashed line is the mean

976 annual precipitation for 1951-2012, excluding years with incomplete seasonal data (columns

977 with an asterisk and one or more missing seasonal totals). Mean total January through May

978 precipitation $(\mathrm{PW})$ is $90 \mathrm{~mm}(\mathrm{SE}=5.2, n=61$; 1951-2012 data). 
Andersen, D.C. - Narrowleaf cottonwood ecohydrology
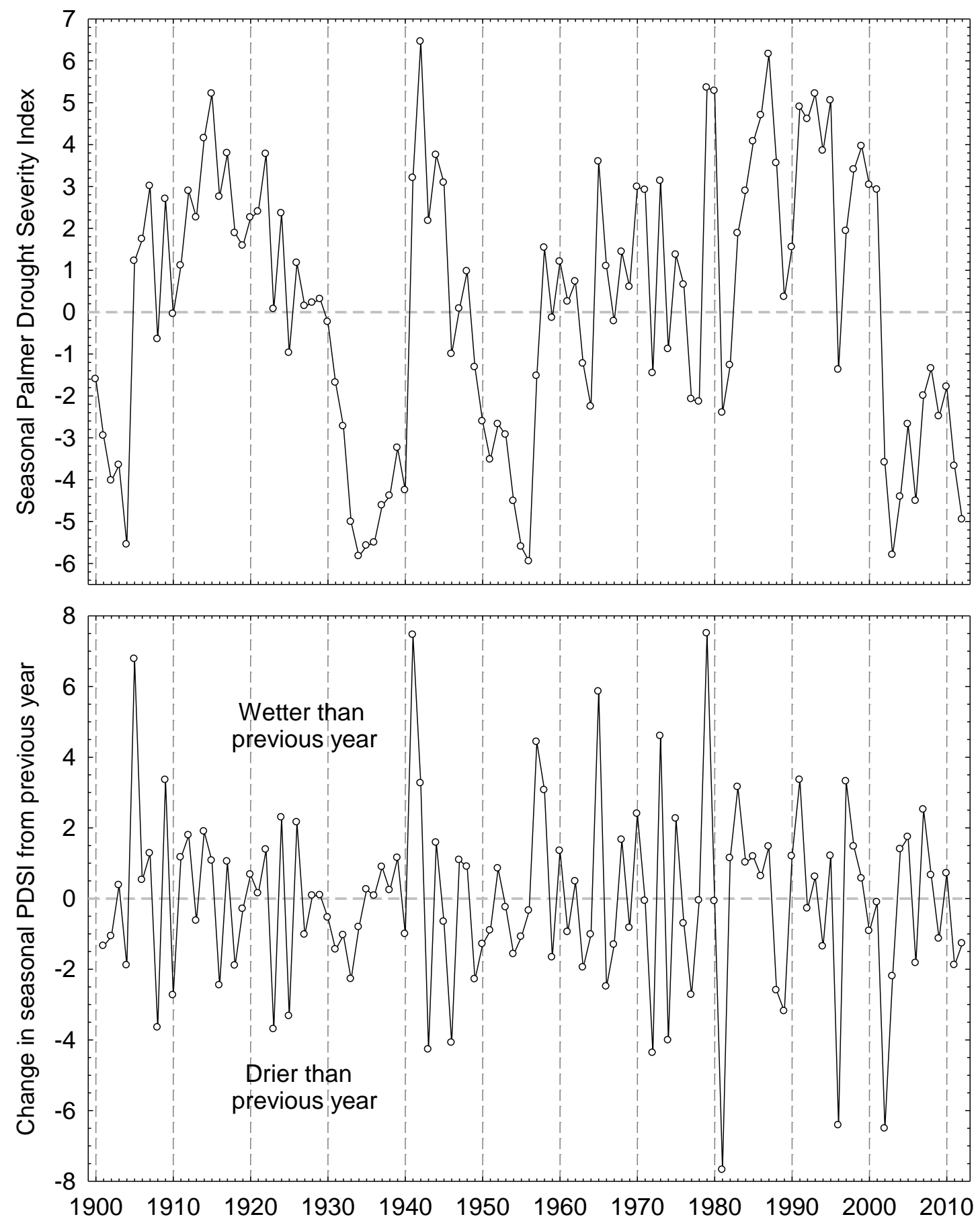
Climate Division 5, which includes the San Luis Valley and the study area. (Lower panel) Change in the value of PDSIs from the prior year's value. An extreme shift to much drier conditions occurred in 1981, 1996, and 2002, and each of those years was preceded by two years 984 with similar, relatively wet PDSIs values. 
Andersen, D.C. - Narrowleaf cottonwood ecohydrology

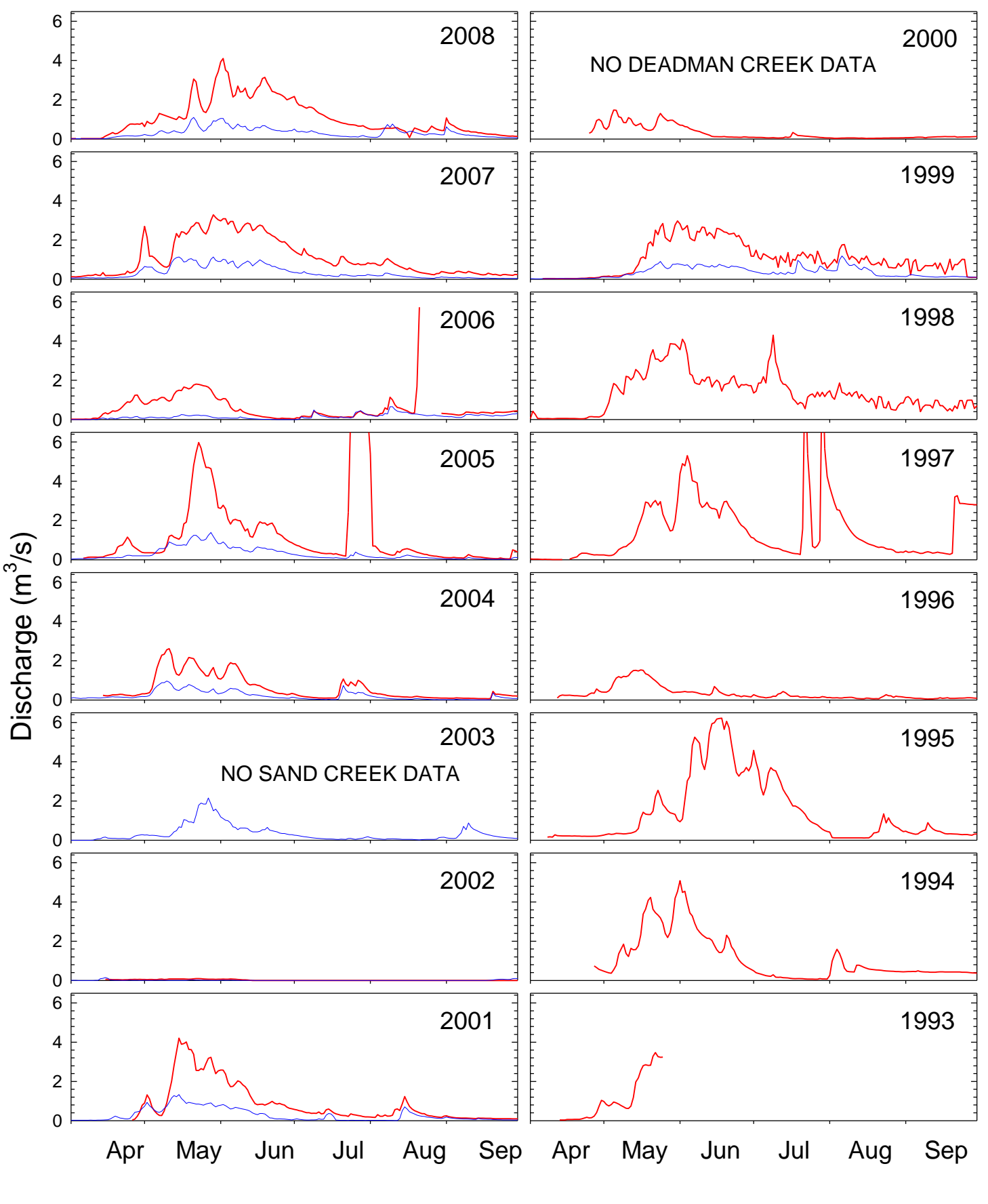

986

987 Figure 5. Measured daily mean discharge in Sand Creek (thick/red line) and Deadman Creek 988 (thin/blue line) during April through September in years 1993 to 2008. There are no Sand Creek 989 data for 2003 nor Deadman Creek data for 2000, and missing data in other years. The limited 990 Sand Creek data for 1993 were not used in analyses. Late summer spikes in Sand Creek 991 discharge represent runoff generated during monsoon-related storm events; gauge malfunction 992 may affect subsequent data collected that year. See text for gauge information. 

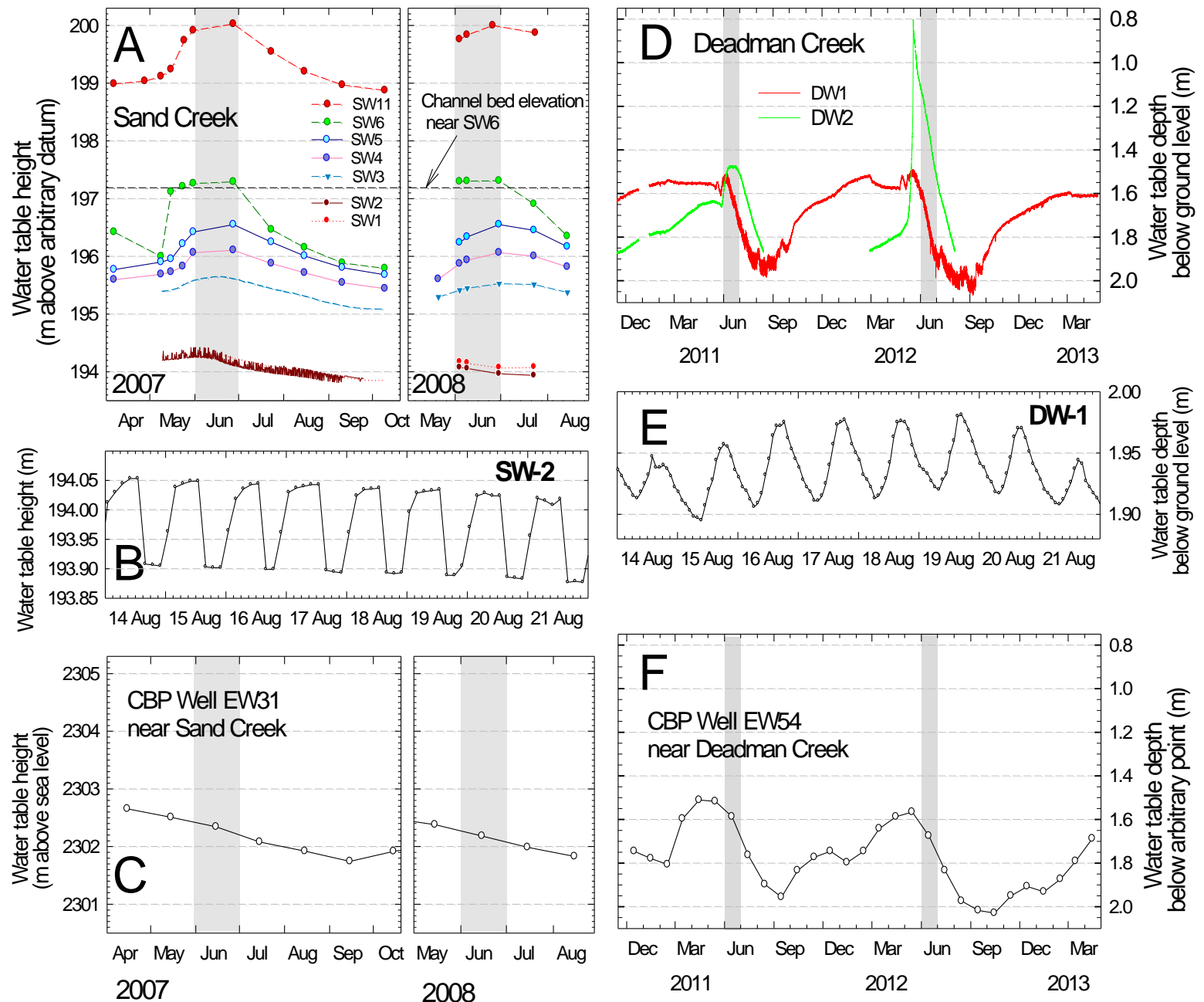

995 Figure 6. (A) Comparative water table dynamics recorded during the 2007 and 2008 growing seasons at seven of the 12 observation wells established at Sand Creek Site S4. Measurements have been adjusted to a common arbitrary datum. Well locations are shown in Figure 2. Wells

998 SW1, SW2 and SW3 were monitored continuously in 2007, whereas the remaining wells were read manually. The low water table at SW6 in May 2007 is probably a measurement error. June is shaded for clarity. (B) Circadian water table fluctuations in Well SW2 during August 2007. (C) Water table dynamics recorded in Closed Basin Project monitoring well EW31 during the same period shown in Panel A. (D) Water table dynamics measured with respect to the local ground surface in Deadman Creek wells DW1 and DW2 during 2011 to 2013. June is shaded for clarity. (E) Circadian water table fluctuations in Well DW1 during August 2011. (F) Water table dynamics recorded in Closed Basin Project monitoring well EW54 during the same period 1006 shown in Panel D. 
Andersen, D.C. - Narrowleaf cottonwood ecohydrology

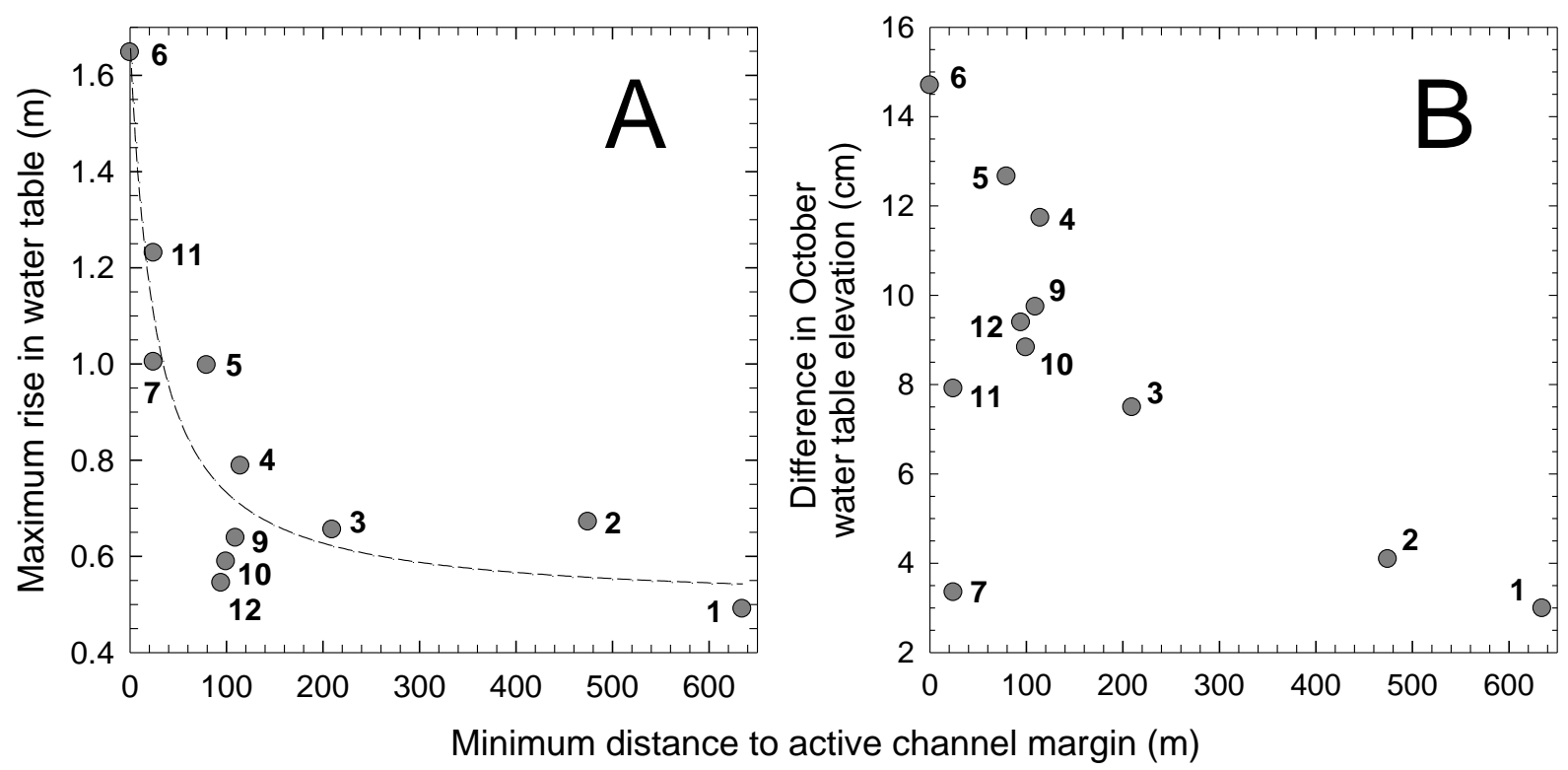

1008

1009

1010 Figure 7. (A) The total rise in the floodplain water table from an annual minimum (autumn

1011 2006) to the following annual maximum (summer 2007) versus distance to the active channel

1012 margin at Sand Creek Site S4. Well numbers are indicated next to symbols. Dashed line is

1013 modified 3-parameter exponential decay fit to the points $\left(P=0.001 ; \mathrm{r}^{2}=0.87\right)$. (B) Scatterplot

1014 showing the difference between the water table elevation in October 2007 and October 2006

1015 plotted against the distance to the active channel for S4 wells. October 2007 water table

1016 elevations were universally higher, but the difference declined with distance from the active

1017 channel margin. Well numbers are indicated next to symbols. 
Andersen, D.C. - Narrowleaf cottonwood ecohydrology

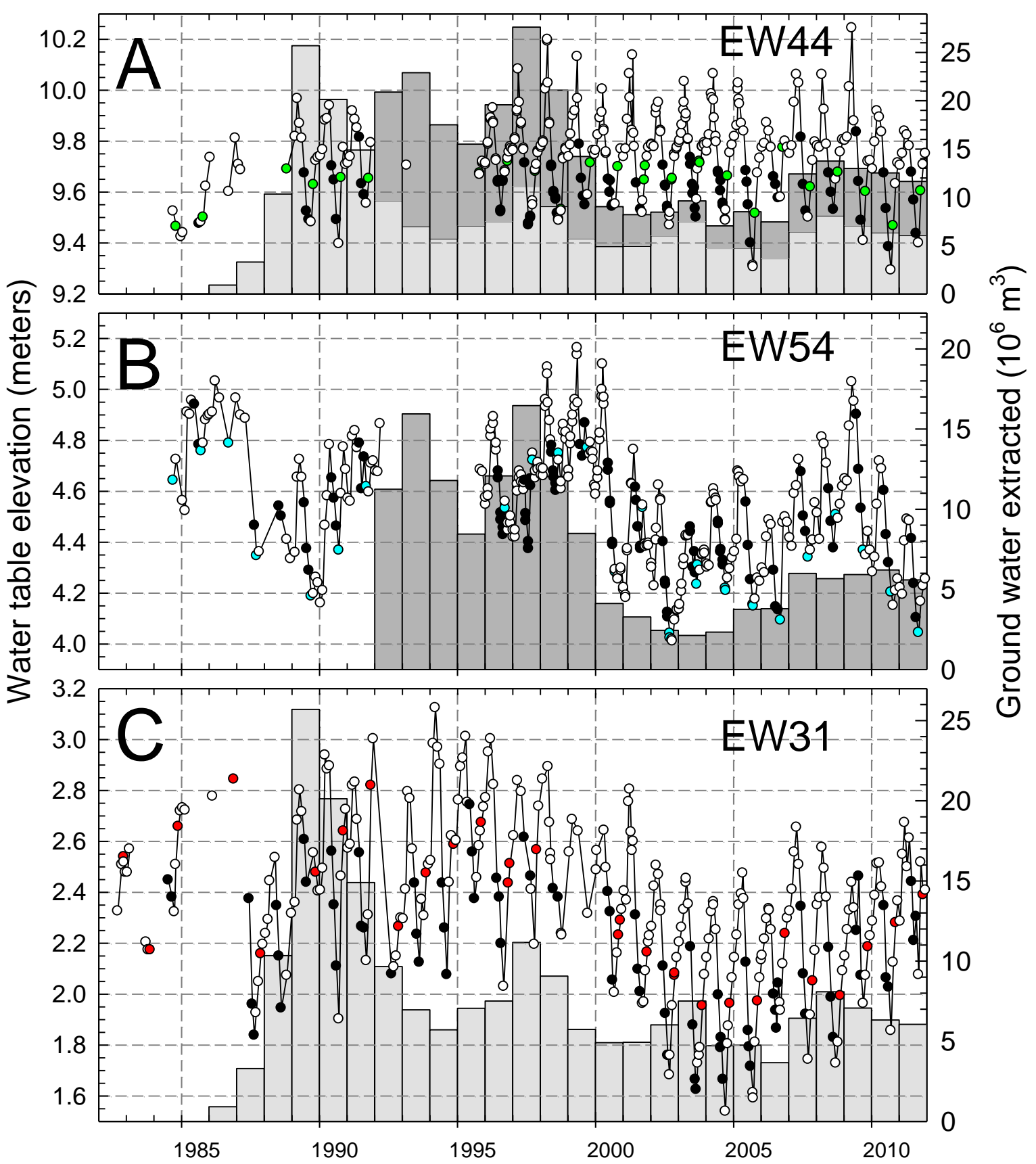

1019

1020

1021

1022

1023

1024

1025

1026

1027

1028

1029

Figure 8. Water table elevation (circles) in Closed Basin Project monitoring wells EW44, EW54, and EW31 plotted over annual pumping volumes (vertical bars) from Stage 3 (light gray) and Stage 4 (dark gray) project areas. Lines connect elevations recorded $<7$ months apart. Elevations with black fill are summer month measurements (June through August). Gray (or colored) circles are September (EW54), October (EW44), or November (EW31) measurements. (A) Well EW44 plotted with stacked bar graph showing total volume extracted from both project areas. (B) EW54 ( 1 km from the lower Deadman Creek channel) with nearby Stage 4 volume data. (C) Well EW31 ( 1 km from the Sand Creek channel) with nearby Stage 3 volume data. Elevations are relative to $2300 \mathrm{~m}$ datum (NAVD88); all panels have the same elevation scale; B and $\mathrm{C}$ also have the same volume scale. 
Andersen, D.C. - Narrowleaf cottonwood ecohydrology
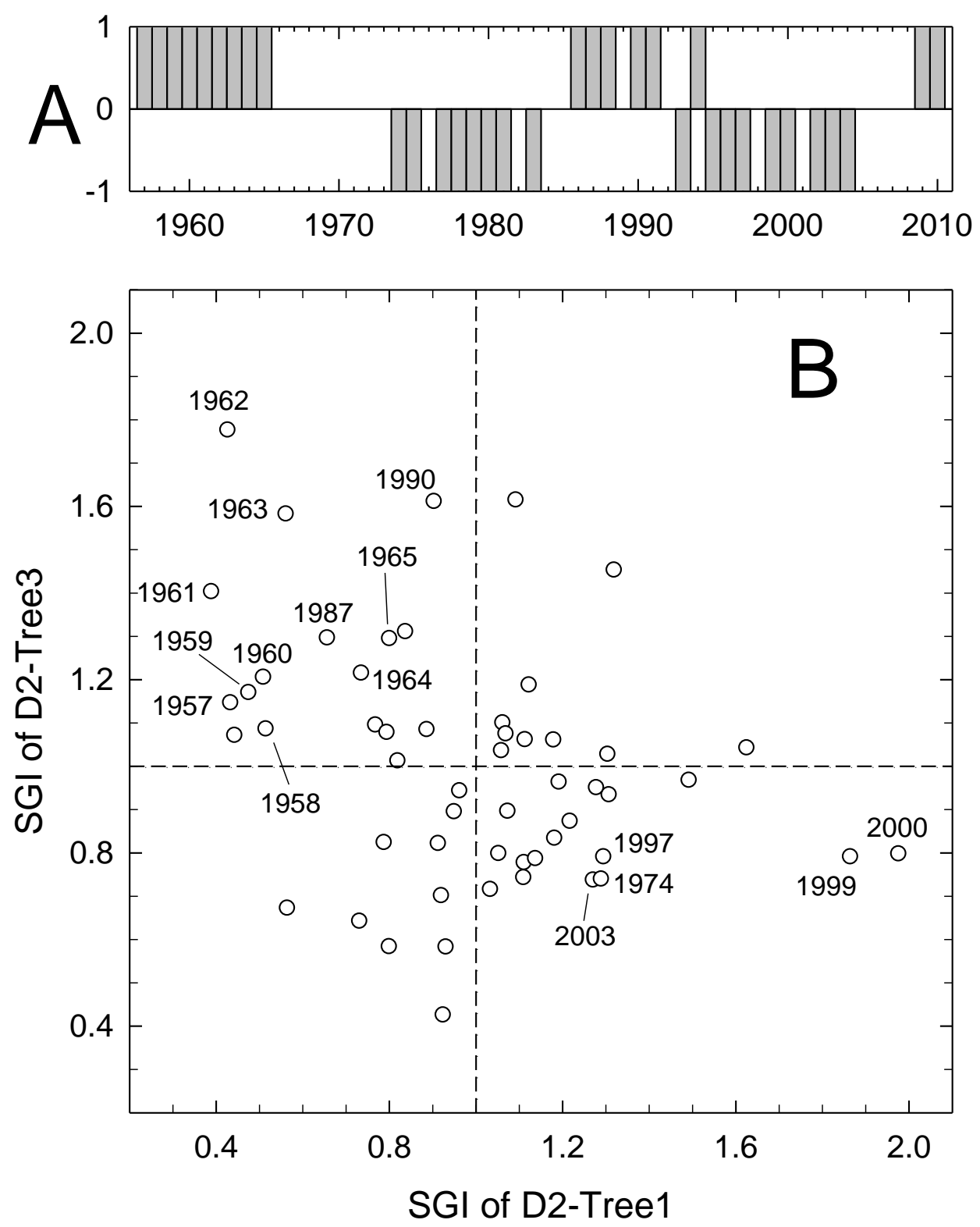

1030

1031

1032

1033

1034

1035

1036

1037

1038

1039

1040
Figure 9. An example of contrary patterns of annual standardized growth index (SGI) values in two neighboring narrowleaf cottonwood trees. Data are from Tree 1 and Tree 3 growing near the channel at Deadman Creek Site D2 and cover years 1958-2010. (A) Upward bars indicate the individual years in which Tree 3 showed above-average growth (SGI > 1) while Tree 1 showed below-average growth (SGI < 1). Downward bars indicate years in which the opposite pattern appeared. (B) A scatterplot of the actual SGI values for each year, with some of the years with greatest growth differences labelled. The points in the upper left and lower right quadrants are represented in $(\mathrm{A})$. 
Andersen, D.C. - Narrowleaf cottonwood ecohydrology

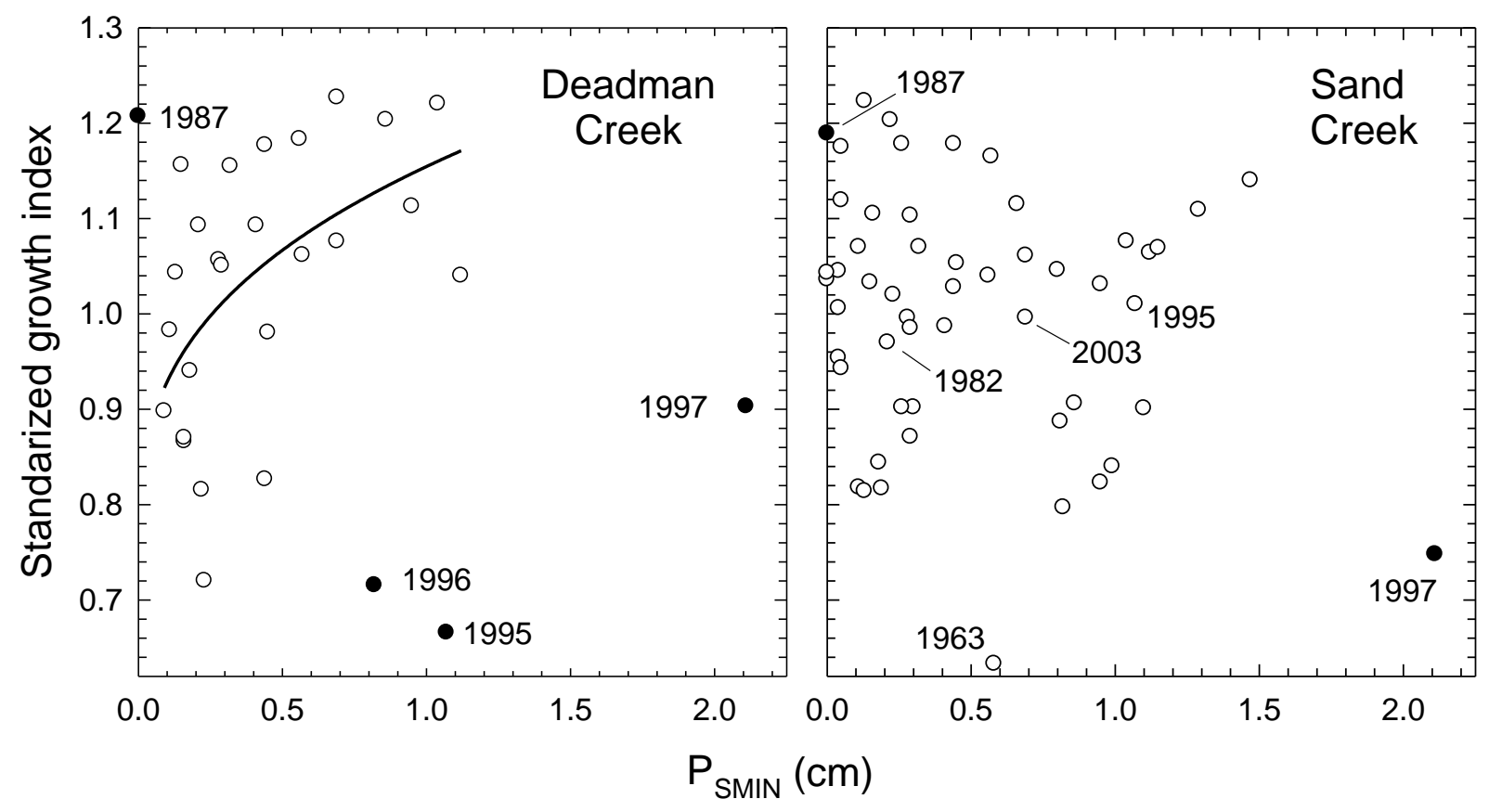

1043 Figure 10. The relationships between mean annual radial growth in narrowleaf cottonwood 1044 growing far from the stream channel and minimum total monthly precipitation during June1045 September (PSMin) for Deadman Creek Site D3 (D3-Far trees) and Sand Creek Site S4 (S4-Far 1046 trees). Both sites are distant from the Sangre de Cristo mountain front (see Figure 1). The fitted 1047 3-parameter power function for Deadman Creek data (solid line; $P=0.026$ ) is based on 198210482010 data with four outlier years (filled circles) removed (see text for details). No relationship 1049 was found for the Sand Creek data with outlier 1997, a legacy-candidate year, excluded. 